Article

\title{
Spin Cross-Over (SCO) Anionic Fe(II) Complexes Based on the Tripodal Ligand Tris(2-pyridyl)ethoxymethane
}

\author{
Emmelyne Cuza $^{1}$, Samia Benmansour ${ }^{2}\left(\mathbb{0}\right.$, Nathalie Cosquer $^{1}\left(\mathbb{D}\right.$, Françoise Conan $\left.^{1}{ }^{(}\right)$, \\ Sébastien Pillet ${ }^{3}$, Carlos J. Gómez-García ${ }^{2}$ and Smail Triki ${ }^{1, *(1)}$ \\ 1 Univ Brest, CNRS, CEMCA, 6 Avenue Le Gorgeu, C.S, 93837-29238 Brest CEDEX 3, France; \\ Emmelyne.Cuza@univ-brest.fr (E.C.); nathalie.cosquer@univ-brest.fr (N.C.); \\ Francoise.Conan@univ-brest.fr (F.C.) \\ 2 Instituto de Ciencia Molecular (ICMol), Departamento de Química Inorgánica, Universidad de Valencia, \\ C/Catedrático José Beltrán 2, 46980 Paterna, Spain; sam.ben@uv.es (S.B.); Carlos.Gomez@uv.es (C.J.G.-G.) \\ 3 Laboratoire de Cristallographie, Résonance Magnétique et Modélisations, UMR 7036, Boulevard des \\ Aiguillettes, BP239 54506 Vandoeuvre-les-Nancy, France; sebastien.pillet@univ-lorraine.fr \\ * Correspondence: smail.triki@univ-brest.fr; Tel.: +33-298-016-146
}

Received: 23 May 2020; Accepted: 5 June 2020; Published: 7 June 2020

\begin{abstract}
Reactions of Fe(II) with the tripodal chelating ligand 1,1,1-tris(2-pyridyl)ethoxymethane (py $\left.{ }_{3} \mathrm{C}-\mathrm{OEt}\right)$ and $(\mathrm{NCE})^{-}$co-ligands $\left(\mathrm{E}=\mathrm{S}, \mathrm{Se}, \mathrm{BH}_{3}\right)$ give a series of mononuclear complexes formulated as $\left[\mathrm{Fe}\left(\mathrm{py}_{3} \mathrm{C}-\mathrm{OEt}\right)_{2}\right]\left[\mathrm{Fe}\left(\mathrm{py}_{3} \mathrm{C}-\mathrm{OEt}\right)(\mathrm{NCE})_{3}\right]_{2} \cdot 2 \mathrm{CH}_{3} \mathrm{CN}$, with $\mathrm{E}=\mathrm{S}$ (1) and $\mathrm{BH}_{3}$ (2). These compounds are the first Fe(II) spin cross-over (SCO) complexes based on the tripodal ligand tris(2-pyridyl)ethoxymethane and on the versatile co-ligands $(\mathrm{NCS})^{-}$and $\left(\mathrm{NCBH}_{3}\right)^{-}$. The crystal structure reveals discrete monomeric isomorph structures formed by a cationic $\left[\mathrm{Fe}\left(\mathrm{py}_{3} \mathrm{C}-\mathrm{OEt}\right)_{2}\right]^{2+}$ complex and by two equivalent anionic $\left[\mathrm{Fe}\left(\mathrm{py}_{3} \mathrm{C}-\mathrm{OEt}\right)(\mathrm{NCE})_{3}\right]^{-}$complexes. In the cations the $\mathrm{Fe}(\mathrm{II})$ is facially coordinated by two $\mathrm{py}_{3} \mathrm{C}-\mathrm{OEt}$ tripodal ligands whereas in the anion the three nitrogen atoms of the tripodal ligand are facially coordinated and the $\mathrm{N}$-donor atoms of the three $(\mathrm{NCE})^{-}$co-ligands occupy the remaining three positions to complete the distorted octahedral environment of the $\mathrm{Fe}(\mathrm{II})$ centre. The magnetic studies show the presence of gradual SCO for both complexes: A one-step transition around $205 \mathrm{~K}$ for $\mathbf{1}$ and a two-step transition for compound 2, centered around $245 \mathrm{~K}$ and $380 \mathrm{~K}$.
\end{abstract}

Keywords: tripodal ligands; iron complex; spin cross-over; infrared spectroscopy; magnetic properties

\section{Introduction}

In the last decade, spin cross-over (SCO) complexes are undoubtedly the most studied molecular systems among switchable materials thanks to their several potential applications, in particular, for the development of new generation electronic devices such as memories, molecular sensors and displays [1-10]. These complexes can be reversibly switched from high-spin (HS) state to the low-spin $(L S)$ state by external physical stimuli such as temperature, pressure, or light irradiation. Even if this spin change can occur in general for some complexes based on transition metal ions with $\mathrm{d}^{4}-\mathrm{d}^{7}$ electronic configurations, the Fe(II) octahedral complexes, with $\mathrm{d}^{6}$ electronic configuration, remain, by far, the most investigated systems during recent decades [11-17]. While almost all the SCO materials reported up today are either cationic or neutral [1-17], the number of anionic complexes exhibiting the SCO phenomenon is relatively limited compared to the several hundreds of examples of neutral and cationic complexes reported every year. To the best of our knowledge, all the anionic SCO complexes are based on Fe(III) [18-23] or Fe(II) [24-30]. For those based on Fe(II), three different 
systems have been studied. The first system, reported in 2003 [24], concerns a series of Fe(II) complexes of chemical formula $\left[\mathrm{Fe}^{\mathrm{II}} \mathrm{H}_{3} \mathrm{~L}^{\mathrm{Me}}\right]\left[\mathrm{Fe}^{\mathrm{II}} \mathrm{L}^{\mathrm{Me}}\right] \mathrm{X}\left(\mathrm{X}^{-}=\mathrm{ClO}_{4}{ }^{-}, \mathrm{BF}_{4}{ }^{-}, \mathrm{PF}_{6}{ }^{-}, \mathrm{AsF}_{6}{ }^{-}, \mathrm{SbF}_{6}{ }^{-}\right)$, based on the hexadentante neutral ligand $\mathrm{H}_{3} \mathrm{~L}^{\mathrm{Me}}$ (tris[2-((2-methylimidazol-4-yl)methylidene)amino)ethyl]amine) and on the deprotonated $\left(\mathrm{L}^{\mathrm{Me}}\right)^{3-}$ anionic form forming a supramolecular 2D-array composed by $\left[\mathrm{Fe}^{\mathrm{II}} \mathrm{H}_{3} \mathrm{~L}^{\mathrm{Me}}\right]^{2+}$ cations and $\left[\mathrm{Fe}^{\mathrm{II}} \mathrm{L}^{\mathrm{Me}}\right]^{-}$anions, both exhibiting SCO. This system can be viewed as interacting anionic and cationic Fe(II) SCO species in a two-dimensional structure. The second example, reported more recently [25], concerns a trinuclear complex $\left[\mathrm{Fe}^{\mathrm{II}}{ }_{3}(\mu-\mathrm{L})_{6}\left(\mathrm{H}_{2} \mathrm{O}\right)_{6}\right]^{6-}$, based on the bridging anionic ligand 4-(1,2,4-triazol-4-yl)ethanedisulfonate) (L), exhibiting a SCO transition above room temperature with a large hysteresis loop $(>85 \mathrm{~K})$. The first example of the third system was reported in 2012 by T. Ishida et al. [26] as the first SCO example based on the rigid tetrakis(2-pyridyl)methane $\left(\mathrm{py}_{4} \mathrm{C}\right.$ ) ligand (see Scheme 1a, $\mathrm{R}=\mathrm{py}$ ). In this example, the $\mathrm{Fe}(\mathrm{II})$ ion in the mononuclear anionic complex, $\left[\mathrm{Fe}\left(\mathrm{py}_{4} \mathrm{C}\right)(\mathrm{NCS})_{3}\right]^{-}$, is surrounded by the $\mathrm{py}_{4} \mathrm{C}$ tripodal ligand acting as tridentate through the nitrogen atoms of three pyridyl groups and by three thiocyanate anions acting as terminal co-ligands (see Scheme $1 b, R=p y$ ). As a result of this work and thanks to the chemical flexibility of the tripodal $\mathrm{py}_{3} \mathrm{C}-\mathrm{R}$ ligand that allows chemical modifications by changing the R groups (see Scheme 1a), the same group has reported in 2015 the two first $\mathrm{SCO}$ anionic complexes with $\left[\mathrm{Me}_{4} \mathrm{~N}\right]^{+}$as counter-ion: $\left[\mathrm{Me}_{4} \mathrm{~N}\right]\left[\mathrm{Fe}\left(\mathrm{py}{ }_{3} \mathrm{C}-\mathrm{OH}\right)(\mathrm{NCS})_{3}\right] \cdot(1-\mathrm{PrOH})_{0.5} \cdot\left(\mathrm{H}_{2} \mathrm{O}\right)_{2}$ [27] and [ $\left.\mathrm{Me}_{4} \mathrm{~N}\right]\left[\mathrm{Fe}\left(\mathrm{py}_{3} \mathrm{C}-\mathrm{Me}\right)(\mathrm{NCS})_{3}\right] \cdot\left(\mathrm{H}_{2} \mathrm{O}\right)[28]$, exhibiting gradual $\mathrm{SCO}$ at 282 and $330 \mathrm{~K}$, respectively. After annealing at $400 \mathrm{~K}$, the first salt led to the new phase: $\left[\mathrm{Me}_{4} \mathrm{~N}\right]\left[\mathrm{Fe}\left(\mathrm{py}_{3} \mathrm{C}-\mathrm{OH}\right)(\mathrm{NCS})_{3}\right] \cdot\left(\mathrm{H}_{2} \mathrm{O}\right)$ that presents an abrupt transition with a thermal hysteretic behavior and a significant heating-rate dependence $[27,28]$. With the objective to understand the effect of the counter-ion and of the functional group of the organic ligand, Ishida et al. have completed their series with two other examples: $\left[(\mathrm{Ph})_{4} \mathrm{P}\right]\left[\mathrm{Fe}\left(\mathrm{py}_{3} \mathrm{C}-\mathrm{Me}\right)(\mathrm{NCS})_{3}\right][29]$ and $\left[\mathrm{Me}_{4} \mathrm{~N}\right]\left[\mathrm{Fe}\left((\mathrm{py})_{3} \mathrm{C}-n-\mathrm{C}_{18} \mathrm{H}_{37}\right)(\mathrm{NCS})_{3}\right]$ [30], exhibiting similar mononuclear structures and gradual SCO at 290 and $186 \mathrm{~K}$, respectively.

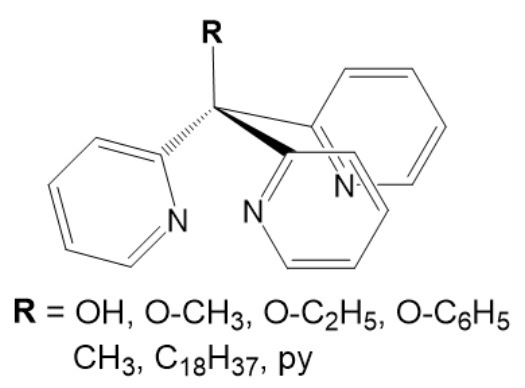

(a)

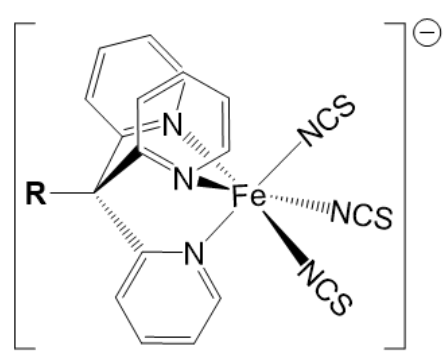

(b)

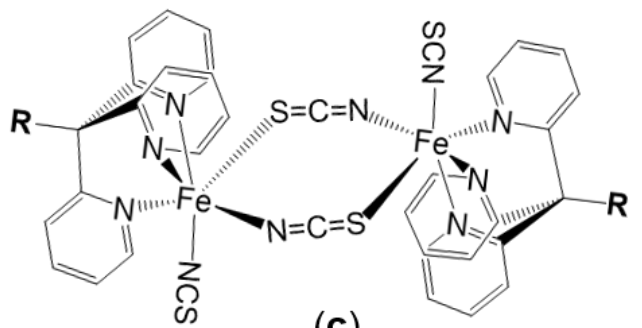

(c)

Scheme 1. (a) Selected functionalized tris(2-pyridyl)methane $\left(\mathrm{py}_{3} \mathrm{CR}\right)$ ligands and examples of tridentate coordination modes observed in anionic (b) and neutral (c) Fe(II) complexes.

In addition to these SCO salts based on the anionic $\left[\mathrm{Fe}\left(\mathrm{py}_{3} \mathrm{C}-\mathrm{R}\right)(\mathrm{NCS})_{3}\right]^{-}$complexes (Scheme 1b), other related systems with different structural features have also been investigated. This concerns the dinuclear $\left[\left\{\mathrm{Fe}\left(\mathrm{py}_{3} \mathrm{C}-\mathrm{OH}\right)(\mathrm{NCS})(\mu-\mathrm{NCS})\right\}_{2}\right] \cdot(\mathrm{PrOH})_{2}$ complex reported in 2015 by T. Ishida as the first $\mathrm{SCO}$ complex with a $\mathrm{FeN}_{5} \mathrm{~S}$ coordination sphere, in which two $\left[\mathrm{Fe}\left(\mathrm{py}_{3} \mathrm{COH}\right)(\mathrm{NCS})\right]$ units are doubly bridged by two end-to-end (NCS) ${ }^{-}$co-ligands [31] (Scheme 1c, $\mathrm{R}=\mathrm{OH}$ ). More recently, some of us have reported a second dinuclear example, $\left[\left\{\mathrm{Fe}\left(\mathrm{py}_{3} \mathrm{C}-\mathrm{OC}_{6} \mathrm{H}_{5}\right)(\mathrm{NCS})(\mu-\mathrm{NCS})\right\}_{2}\right]$, based on 
a similar tripodal ligand (see Scheme $1 \mathrm{c}, \mathrm{R}=\mathrm{OC}_{6} \mathrm{H}_{5}$ ), with a double $\mu-\mathrm{kN}$ : $\mathrm{KS}-\mathrm{SCN}$ bridge in a head-to-tail configuration [32]. However, the magnetic studies of this compound revealed the presence of ferromagnetic interactions $\left(J_{\mathrm{FeFe}}=+1.08 \mathrm{~cm}^{-1}\right)$ and the absence of any SCO transition. These two uncommon dinuclear complexes with similar molecular structures exhibiting very different magnetic properties allowed us to perform experimental and theoretical magneto-structural studies that revealed that the large $\mathrm{N}_{\mathrm{py}}-\mathrm{Fe}^{\mathrm{II}}$ distances and bent N-bound terminal $\mathrm{kN}-\mathrm{SCN}$ ligands favour the HS state of the $\mathrm{Fe}^{\mathrm{II}}$ ions, while short $\mathrm{N}_{\text {tripodal }}-\mathrm{Fe}^{\mathrm{II}}$ distances and almost linear Fe-N-C angles favour the $L S$ state, allowing the SCO behaviour [32]. At the same time, we have enriched these uncommon polynuclear systems with a new Fe(II) 1-D coordination polymer, $\left[\left\{\mathrm{Fe}\left(\mathrm{py}_{3}-\mathrm{OMe}\right)(\mathrm{NCS})(\mu-\mathrm{NCS})\right\}_{\mathrm{n}}\right]$, based on a similar tripodal ligand (see Scheme $1 \mathrm{a}: \mathrm{R}=\mathrm{OMe}$ ) and thiocyanato ligand acting as a $\mu-\mathrm{kN}$ : $\mathrm{kS}-\mathrm{SCN}$ single bridge in a head-to-tail configuration, for which the magnetic studies showed an abrupt and complete HS/LS transition at $199 \mathrm{~K}$ [33].

In view of the above observations and in order to further investigate the effect of the functional group of the tripodal ligand and that of the anionic co-ligand, on the structural features and on the SCO characteristics (e.g., transition temperatures, cooperativity and presence of the LIESST effect), we have developed an extensive synthetic work including: (i) Several functionalizations of the $p y_{3} C-R$ tripodal ligand by varying the size and the flexibility of the $\mathrm{R}$ functional group and (ii) other different anionic co-ligands such as (NCSe) ${ }^{-}$and $\left(\mathrm{NCBH}_{3}\right)^{-}$or more sophisticated ones such as cyanocarbanion units involving several coordinating nitrile groups, and for which the geometry allows them to act as either terminal or multi-bridging co-ligands. In the present work, we report the syntheses, structural characterization, variable temperature infrared spectroscopy and magnetic properties of the two isomorph compounds: $\left[\mathrm{Fe}\left(\mathrm{py}_{3} \mathrm{C}-\mathrm{OEt}\right)_{2}\right]\left[\mathrm{Fe}\left(\mathrm{py}{ }_{3} \mathrm{C}-\mathrm{OEt}\right)(\mathrm{NCE})_{3}\right]_{2} \cdot 2 \mathrm{CH}_{3} \mathrm{CN}$, with $\mathrm{E}=\mathrm{S}(\mathbf{1})$ and $\mathrm{BH}_{3}(\mathbf{2})$ that are the first $\mathrm{Fe}(\mathrm{II})$ spin $\mathrm{SCO}$ systems involving the tripodal ligand tris(2-pyridyl)ethoxymethane $\left(\mathrm{py}_{3} \mathrm{C}-\mathrm{OEt}\right)$ and $(\mathrm{NCS})^{-}$and $\left(\mathrm{NCBH}_{3}\right)^{-}$as versatile co-ligands.

\section{Results and Discussion}

\subsection{Syntheses}

The synthesis of tris(pyridin-2-yl)ethoxymethane (py ${ }_{3} \mathrm{C}-\mathrm{OEt}$ ) was carried out in two different steps, following previous published procedures [34,35] with slight modifications: (i) The reaction of one equivalent of 2-bromopyridine in the presence of n-BuLi at $-80^{\circ} \mathrm{C}$ in THF led to 2-Pyridyllithium. The resulting solution was then treated with one equivalent of $2,2^{\prime}$-dipyridyl ketone leading to a white powder which was characterized as tris(pyridin-2-yl)methanol $\left(\mathrm{py}_{3} \mathrm{COH}\right)$ after purification with a chemical yield of $88 \%$, significantly higher than that reported in references $34-35$ (See detailed synthesis and Figures S1-S3 in SI); (ii) the second step consists of a reaction in dimethylformamide under $\mathrm{N}_{2}$ atmosphere at $0^{\circ} \mathrm{C}$ of tris(pyridin-2-yl)ethoxymethane in the presence of sodium hydride and iodoethane, leading to a white powder which was characterized as tris(pyridin-2-yl)ethoxymethane (py ${ }_{3} \mathrm{C}-\mathrm{OEt}$ ) with a chemical yield of $85 \%$ (See detailed synthesis and Figures S4-S6). Compounds 1 and 2 were obtained as orange and red single crystals, respectively, by mixing a solution of the $\mathrm{NCE}^{-}$ co-ligand $\mathrm{E}=\mathrm{S}(\mathbf{1})$ and $\mathrm{BH}_{3}(\mathbf{2})$ with a solution of $\mathrm{FeCl}_{2}$ and tris(pyridin-2-yl)ethoxymethane at $-32{ }^{\circ} \mathrm{C}$.

\subsection{Description of the Structure}

According to the spin state derived from the colour at room temperature and to the magnetic properties detailed below, for the two compounds $\mathbf{1}$ and 2, the crystal structure of $\left[\mathrm{Fe}\left(\mathrm{py}_{3} \mathrm{C}-\mathrm{OEt}\right)_{2}\right]\left[\mathrm{Fe}\left(\mathrm{py}_{3} \mathrm{C}-\mathrm{OEt}\right)(\mathrm{NCS})_{3}\right]_{2} \cdot 2 \mathrm{CH}_{3} \mathrm{CN}(\mathbf{1})$ was determined at $293 \mathrm{~K}$ and $100 \mathrm{~K}$, while the structure of $\left[\mathrm{Fe}\left(\mathrm{py}_{3} \mathrm{C}-\mathrm{OEt}\right)_{2}\right]\left[\mathrm{Fe}\left(\mathrm{py}_{3} \mathrm{C}-\mathrm{OEt}\right)\left(\mathrm{NCBH}_{3}\right)_{3}\right]_{2} \cdot 2 \mathrm{CH}_{3} \mathrm{CN}(2)$ was determined at $200 \mathrm{~K}$. The unit cell parameters, crystal and refinement data, and the pertinent bond distances and angles are summarized in Tables 1 and 2, respectively, for both compounds. 
Table 1. Crystal data and structure refinement of complexes $\left[\mathrm{Fe}\left(\mathrm{py}_{3} \mathrm{C}-\mathrm{OEt}\right)_{2}\right]\left[\mathrm{Fe}\left(\mathrm{py}_{3} \mathrm{C}-\mathrm{OEt}\right)(\mathrm{NCE})_{3}\right]_{2} \cdot 2 \mathrm{CH}_{3} \mathrm{CN}\left(\mathrm{E}=\mathrm{S}(\mathbf{1}), \mathrm{BH}_{3}(\mathbf{2})\right)$.

\begin{tabular}{|c|c|c|c|}
\hline & \multicolumn{2}{|c|}{1} & 2 \\
\hline Temperature/K & 293 & 100 & 200 \\
\hline Color & Orange & Red & Red \\
\hline Formula & \multicolumn{2}{|c|}{$\mathrm{C}_{82} \mathrm{H}_{74} \mathrm{Fe}_{3} \mathrm{~N}_{20} \mathrm{O}_{4} \mathrm{~S}_{6}$} & $\mathrm{C}_{82} \mathrm{H}_{92} \mathrm{Fe}_{3} \mathrm{~N}_{20} \mathrm{O}_{4} \mathrm{~B}_{6}$ \\
\hline F. Wt. & \multicolumn{2}{|c|}{1763.52} & 1654.16 \\
\hline Space group & \multicolumn{2}{|c|}{$P-1$} & $P-1$ \\
\hline Crystal system & \multicolumn{2}{|c|}{ Triclinic } & Triclinic \\
\hline$A / \AA$ & $11.6683(5)$ & $11.432(5)$ & $11.6827(8)$ \\
\hline$B / \AA$ & $11.9026(7)$ & $11.829(5)$ & $12.0204(10)$ \\
\hline$C / \AA$ & $17.1711(9)$ & $16.857(5)$ & $16.9162(11)$ \\
\hline$A /^{\circ}$ & $78.192(5)$ & $78.072(5)$ & $78.389(6)$ \\
\hline$B /^{\circ}$ & $88.279(4)$ & $88.037(5)$ & $87.805(6)$ \\
\hline$\Gamma /{ }^{\circ}$ & $66.544(5)$ & $65.879(5)$ & $65.767(7)$ \\
\hline$V / \AA^{3}$ & $2137.9(2)$ & 2032.4(14) & 2119.3(3) \\
\hline Z & 1 & 1 & 1 \\
\hline$\rho_{\text {calc/ }} \mathrm{g} \mathrm{cm}^{-3}$ & 1.370 & 1.441 & 1.296 \\
\hline $2 \theta$ range $(\mathrm{deg})$ & $6.834-58.856$ & $6.527-58.824$ & $6.508-58.484$ \\
\hline Total reflections & 18,918 & 26,672 & 15,809 \\
\hline Unique reflections/ $R_{\text {int }}$ & $9830 / 0.0458$ & $9534 / 0.0722$ & $9657 / 0.0701$ \\
\hline Data with $I>2 \sigma(I)$ & 5988 & 6916 & 5051 \\
\hline $\mathrm{N}_{\mathrm{var}}$ & 523 & 523 & 550 \\
\hline $\mathrm{R}_{1}{ }^{\mathrm{a}}$ on $I>2 \sigma(I) / w \mathrm{R}_{2}{ }^{\mathrm{b}}$ (all) & $0.0692 / 0.2053$ & $0.0605 / 0.1752$ & $0.0823 / 0.2752$ \\
\hline $\operatorname{GooF}^{\mathrm{c}}$ on $\mathrm{F}^{2}$ & 1.028 & 1.066 & 0.997 \\
\hline$\Delta \rho_{\max }\left(\mathrm{e} \AA^{-3}\right) / \Delta \rho_{\min }\left(\mathrm{e}^{-3}\right)$ & $0.892 /-0.703$ & $2.110 /-1.047$ & $1.177 /-1.490$ \\
\hline
\end{tabular}

Table 2. Fe-N bond lengths $(\AA)$ and $\sum$ and $\theta$ distortion parameters $\left(^{\circ}\right)$ for compounds $\mathbf{1}$ and 2.

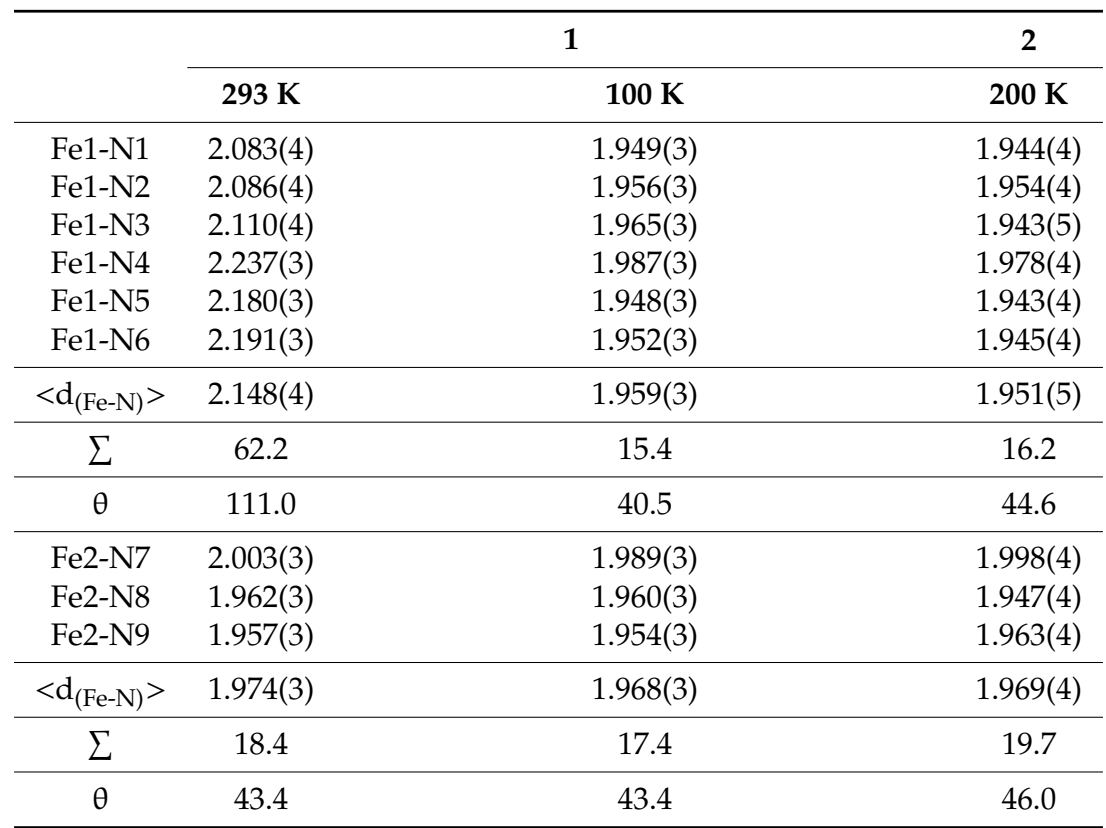

$\Sigma$ is the sum of the deviation from $90^{\circ}$ of the 12 cis angles of the $\mathrm{FeN}_{6}$ octahedron; $\Theta$ is the sum of the deviation from $60^{\circ}$ of the 24 trigonal angles of the projection of the FeN6 octahedron onto its trigonal faces [36].

The crystallographic structural parameters (chemical formula, space group, cell parameters) clearly reveal that both compounds, $\left[\mathrm{Fe}\left(\mathrm{py}_{3} \mathrm{C}-\mathrm{OEt}\right)_{2}\right]\left[\mathrm{Fe}\left(\mathrm{py}_{3} \mathrm{C}-\mathrm{OEt}\right)(\mathrm{NCE})_{3}\right]_{2} \cdot 2 \mathrm{CH}_{3} \mathrm{CN}(\mathrm{E}=\mathrm{S}(\mathbf{1})$ and 
$\left.\mathrm{BH}_{3}(2)\right)$ are isomorph and, therefore, we can expect that main structural differences should arise from the slight differences of their chemical formulae $\left((\mathrm{NCS})^{-}\right.$for $\mathbf{1}$ and $\left(\mathrm{NCBH}_{3}\right)^{-}$for $\left.\mathbf{2}\right)$. The asymmetric unit of both structures contains one $\left[\mathrm{Fe}\left(\mathrm{py}_{3} \mathrm{C}-\mathrm{OEt}\right)_{2}\right]^{2+}$ cation $(\mathrm{Fe} 2$ ion) centred on a crystallographic inversion centre, one $\left[\mathrm{Fe}\left(\mathrm{py}_{3} \mathrm{C}-\mathrm{OEt}\right)(\mathrm{NCE})_{3}\right]^{-}$anion $(\mathrm{Fe} 1 \mathrm{ion})$ and an acetonitrile solvent molecule, both located on general positions (Figure 1 and Figure S7). The Fe(II) ions in both complex units are hexa-coordinated by six $\mathrm{N}$ atoms: in the $\left[\mathrm{Fe}\left(\mathrm{py}_{3} \mathrm{C}-\mathrm{OEt}\right)_{2}\right]^{2+}$ cations, the $\mathrm{Fe}(\mathrm{II})$ ion $(\mathrm{Fe} 2)$ is facially coordinated by two crystallographically equivalent ( $\mathrm{py}_{3} \mathrm{C}-\mathrm{OEt}$ ) tripodal ligands, through the six nitrogen atoms arising from the three pyridyl groups of each tridentate ligand (N7, N8, N9, and N7 ${ }^{(\mathrm{i})}$, $\left.\mathrm{N} 8^{(\mathrm{i})}, \mathrm{N} 9^{(\mathrm{i})}\right)$, while the $\mathrm{Fe}(\mathrm{II})$ ion $(\mathrm{Fe} 1)$ of the anionic complex, $\left[\mathrm{Fe}\left(\left(\mathrm{py}{ }_{3} \mathrm{C}-\mathrm{OEt}\right)(\mathrm{NCS})_{3}\right)\right]^{-}$, is surrounded by the three nitrogen atoms (N4, N5, N6) arising from the three pyridyl groups of the tripodal ligand and from the three $(\mathrm{NCE})^{-}$anions acting as terminal $\mathrm{kN}-\mathrm{SCN}$ terminal co-ligands $(\mathrm{N} 1, \mathrm{~N} 2, \mathrm{~N} 3)$ to complete the distorted octahedral environment of the iron(II) ion (Figure 1). Examination of the Fe-N bond distances and N-Fe-N bonds angles (see below) allows us to describe the metal environment as distorted $\mathrm{FeN}_{6}$ octahedrons in both anionic and cationic complexes in the two compounds ( 1 and 2). The three Fe2-N bond distances (Table 2) in the $\left[\mathrm{Fe}\left(\mathrm{py}_{3} \mathrm{C}-\mathrm{OEt}\right)_{2}\right]^{2+}$ cationic units observed for compounds 1 and 2 (Fe2-N7, Fe2-N8 and Fe2-N9) are quite similar and did not show any significant differences with temperature as indicated by the averaged $\left\langle\mathrm{d}_{(\mathrm{Fe} 2 \mathrm{~N})}>\right.$ values depicted in Table 2 (<Fe2-N>:1.974(3) and 1.968(3) A for 1 at 293 and $100 \mathrm{~K}$, respectively, and 1.969(4) $\AA$ at $200 \mathrm{~K}$ for 2). This low distortion of the coordination sphere with respect to the $\mathrm{O}_{\mathrm{h}}$ symmetry in compound 1 (293 and $100 \mathrm{~K})$ and $2(200 \mathrm{~K})$ is clearly confirmed by almost similar values of their corresponding angular distortion parameter $\left(\sum\right)$ [36] depicted in Table 2 (18.4 and 17.4 for 1 at 293 and $100 \mathrm{~K}$, respectively, and $19.7^{\circ}$ for 2 ). In contrast, the six Fe1-N bond distances in the anionic complex of compound 1 at $293 \mathrm{~K}$ show significant differences (Table 2). Thus, the three Fe1-N distances from the N atoms (N1, $\mathrm{N} 2$ and N3) of the terminal kN-SCN ligands (2.083(4), 2.086(4) and 2.110(4) $\AA$ ) are shorter than the bond distances of the nitrogen atoms (N4, N5 and N6) of the tridentate rigid tripodal ligand (2.237(3), 2.180(3), 2.191(3) ^). This deformation of the coordination sphere is further confirmed by the bond angles that deviate considerably from the ideal values (the cis angles range from $79.16^{\circ}$ to $94.90^{\circ}$ whereas the trans angles are in the range $167.52^{\circ}$ to $174.87^{\circ}$ ) and by the relatively high values of the distortion parameter $\left(\Sigma=62.2^{\circ}\right)$ [36]. At low temperature $(100 \mathrm{~K})$, this strong distortion is clearly reduced as shown by the six Fe1-N almost equivalent bond distances and by a much lower distortion parameter $\left(\Sigma=15.4^{\circ}\right)$. Similarly, the anionic complex $\left[\mathrm{Fe}\left(\mathrm{py}_{3} \mathrm{C}-\mathrm{OEt}\right)\left(\mathrm{NCBH}_{3}\right)_{3}\right]^{-}$part of compound 2 at $200 \mathrm{~K}$, displays equivalent Fe1-N bond distances (1.943-1.978 $\AA$ ) and low distortion parameter $\left(\Sigma=16.2^{\circ}\right)$ which are almost similar to those observed for the cationic units $\left[\mathrm{Fe}\left(\mathrm{py}{ }_{3} \mathrm{C}-\mathrm{OEt}\right)_{2}\right]^{2+}$ of $\mathbf{1}$ and 2. $\left(\Sigma=17.4-19.7^{\circ}\right)$.
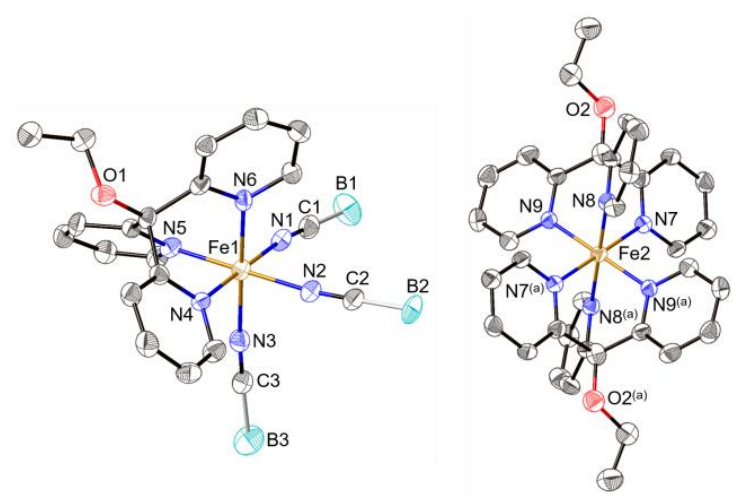

Figure 1. View of the anionic $\left[\mathrm{Fe}\left(\mathrm{py}_{3} \mathrm{C}-\mathrm{OEt}\right)\left(\mathrm{NCBH}_{3}\right)_{3}\right]^{-}$and the dication $\left[\mathrm{Fe}\left(\mathrm{py}{ }_{3} \mathrm{C}-\mathrm{OEt}\right)_{2}\right]^{2+}$ complexes in $\left[\mathrm{Fe}\left(\mathrm{py}_{3} \mathrm{C}-\mathrm{OEt}\right)_{2}\right]\left[\mathrm{Fe}\left(\mathrm{py}_{3} \mathrm{C}-\mathrm{OEt}\right)\left(\mathrm{NCBH}_{3}\right)_{3}\right]_{2} \cdot 2 \mathrm{CH}_{3} \mathrm{CN}$ (2) showing the atom labelling scheme and the coordination environment of the two $\mathrm{Fe}(\mathrm{II})$ ions ( $\mathrm{Fe} 1$ and $\mathrm{Fe} 2)$. Similar structure for $\left[\mathrm{Fe}\left(\mathrm{py}_{3} \mathrm{C}-\mathrm{OEt}\right)_{2}\right]\left[\mathrm{Fe}\left(\mathrm{py}_{3} \mathrm{C}-\mathrm{OEt}\right)(\mathrm{NCS})_{3}\right]_{2} \cdot 2 \mathrm{CH}_{3} \mathrm{CN}(\mathbf{1})$. Codes of equivalent positions: $(\mathrm{a})=-\mathrm{x},-\mathrm{y},-\mathrm{z}$. 
Finally, it is worthy to note that the different coordination spheres described above can be highlighted according to the values of the Fe-N distances and of the distortion parameters which are known to be highly sensitive to the spin state of metal ion. Indeed, the spin state (high-spin (HS) or low-spin (LS)) of each Fe(II) ion can be assigned according to the average value of the Fe- $\mathrm{N}$ bond distances $\left(<\mathrm{Fe}-\mathrm{N}>_{L S} \approx 2.0 \AA ;<\mathrm{Fe}-\mathrm{N}>_{H S} \approx 2.2 \AA\right)$ and to the value of the distortion parameters since high degree of distortion of the $\mathrm{FeN}_{6}$ octahedron is indicative of HS configuration [11-17,36]. Ultimately, the $<$ Fe-N $>$ values (1.974(3) and 1.968(3) $\AA$ for 1 at 293 and $100 \mathrm{~K}$, respectively, and 1.969(4) $\AA$ for 2 at $200 \mathrm{~K})$ and the relatively low $\Sigma$ parameters $\left(18.4^{\circ}\right.$ for $\mathbf{1}$ at $293 \mathrm{~K}, 17.4^{\circ}$ for $\mathbf{1}$ at $100 \mathrm{~K}$ and $19.7^{\circ}$ for 2$)$ observed for the cationic complexes $\left[\mathrm{Fe}\left(\mathrm{py}_{3} \mathrm{C}-\mathrm{OEt}\right)_{2}\right]^{2+}$ in both compounds are characteristic of the $L S$ state. In contrast, the much more distorted coordination sphere observed for the anionic complex in 1 at $293 \mathrm{~K}\left(<\mathrm{Fe}-\mathrm{N}>=2.148(4) \AA, \Sigma=62.2^{\circ}, \theta=111.0^{\circ}\right)$, associated with its lower distortions $\left(\Sigma=15.4^{\circ}\right.$, $\left.\theta=40.5^{\circ}\right)$ and to significant contraction $(<\mathrm{Fe}-\mathrm{N}>=1.959(3) \AA)$ at $100 \mathrm{~K}$, reveal the presence of a SCO in compound $\mathbf{1}$ (see discussion below).

\subsection{Variable Temperature Magnetic Properties and Infrared Spectroscopy}

In line with the structural conclusions above mentioned, variable temperature susceptibility measurements were performed in the temperature range $2-400 \mathrm{~K}$ for $\mathbf{1}$ and $2-500 \mathrm{~K}$ for $\mathbf{2}$. The thermal variation of the product of the molar magnetic susceptibility times the temperature $\left(\chi_{m} T\right)$ are shown in Figure 2 for both complexes.

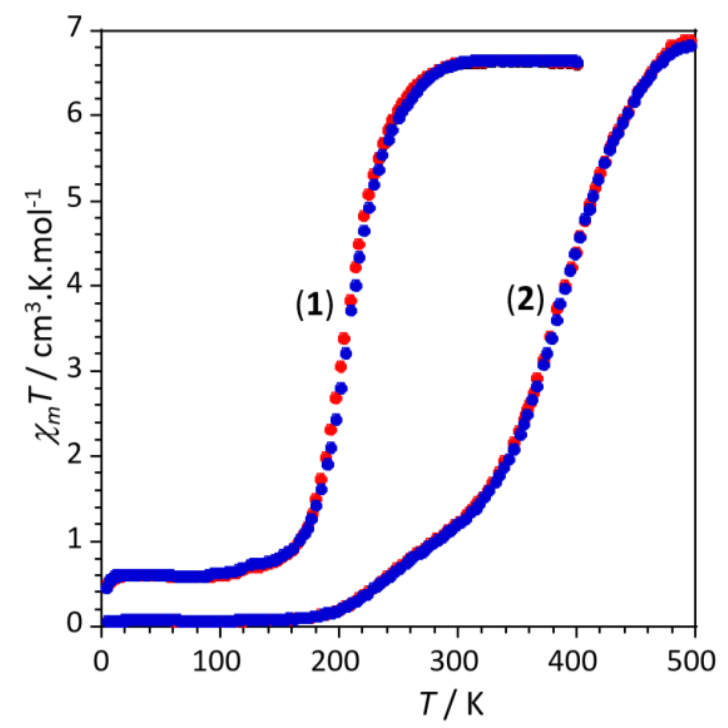

Figure 2. Thermal variation of the $\chi_{m} T$ product for complexes $\mathbf{1}$ and $\mathbf{2}$ in the cooling (blue dots) and warming (red dots) scans.

The $\chi_{\mathrm{m}} T$ values per formula (two Fe(II) ions) at $400 \mathrm{~K}$ for compound $\mathbf{1}\left(\approx 6.7 \mathrm{~cm}^{3} \mathrm{~K} \mathrm{~mol}^{-1}\right)$ and at $500 \mathrm{~K}$ for compound $2\left(\approx 6.9 \mathrm{~cm}^{3} \mathrm{~K} \mathrm{~mol}^{-1}\right)$ are the expected spin only values for two isolated metal ions with $S=2$ and $\mathrm{g} \approx 2.1$ and indicate the presence of two magnetically isolated Fe(II) ions in the HS state $(S=2)$ [11-17]. Upon cooling, the $\chi_{\mathrm{m}} T$ value of 1 remains almost constant down to approximately $245 \mathrm{~K}$ where it shows a quite abrupt decrease reaching a plateau of ca. $0.65 \mathrm{~cm}^{3} \mathrm{~K} \mathrm{~mol}^{-1}$ below $150 \mathrm{~K}$, corresponding to a residual HS fraction of ca. $10 \%$. This behaviour indicates the presence of an incomplete $H S$ to $L S$ transition at $T_{1 / 2}=205 \mathrm{~K}$, as also revealed by the thermochromism observed in the single crystals (orange at $293 \mathrm{~K}$ and red below $150 \mathrm{~K}$ ). The $\chi_{\mathrm{m}} T$ product of 2 shows an abrupt decrease from $500 \mathrm{~K}$ until approximately $360 \mathrm{~K}$ and then decreases in a much more gradual way reaching a value of $0.04 \mathrm{~cm}^{3} \mathrm{~K} \mathrm{~mol}^{-1}$ at ca. $180 \mathrm{~K}$ that remains constant below this temperature, indicating the presence of a complete and gradual HS to LS two-step-like transition centred at around $245 \mathrm{~K}$ and $380 \mathrm{~K}$. For both complexes the magnetic properties were measured in both cooling and warming modes, but 
no significant hysteretic effects were detected. We have also performed photomagnetic studies of both samples by irradiating the samples with a green laser at $10 \mathrm{~K}$ for several hours without detecting any noticeable increase of the magnetic moment in both samples.

To confirm the Fe(II) spin state at high and low temperatures, the presence of the incomplete $H S$ to $L S$ transition for 1 with a residual HS fraction of ca. $10 \%$ in the $L S$ region (see Figure 2) and the presence of an almost complete spin transition for 2, we have performed infrared spectroscopy in the $2150-2200 \mathrm{~cm}^{-1}$ range corresponding to the fundamental stretching vibration of the NCS and $\mathrm{NCBH}_{3}$ moieties. It is well known that the intensity of these stretching vibrations is very sensitive to the spin state of the metal ion [37-43]. According to the thermal dependences of the $\chi_{m} T$ products depicted in Figure 2 for the two complexes, we have studied the NCS stretching vibrations for 1 at 300 and $150 \mathrm{~K}$, and the $\mathrm{NCBH}_{3}$ vibrations at 500 and $170 \mathrm{~K}$ for 2 . The final infrared spectra in the region of the $\mathrm{C}-\mathrm{N}$ frequency for the $H S$ and $L S$ of each compound are depicted in Figure 3.

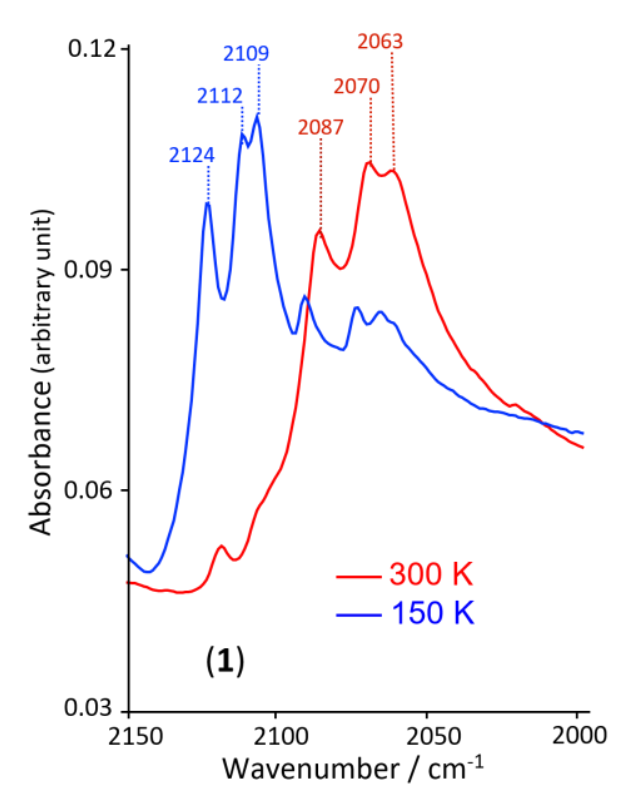

a)

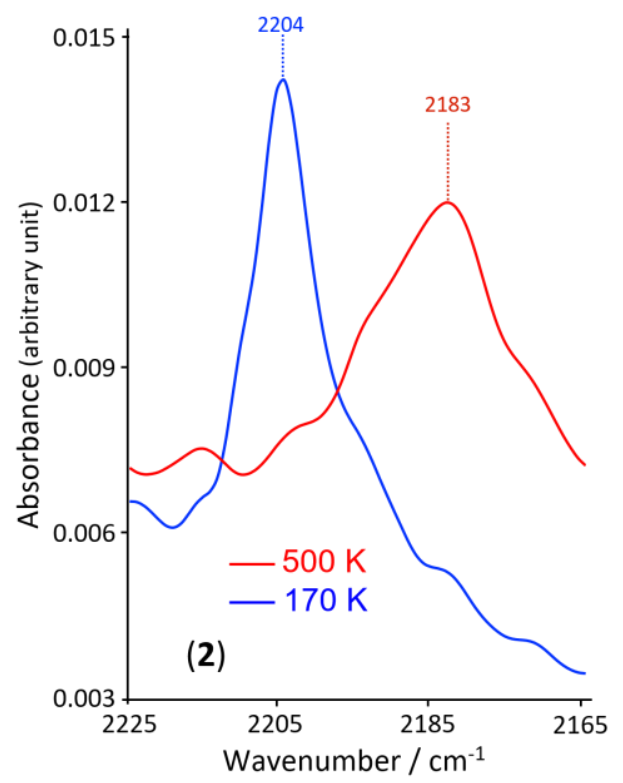

b)

Figure 3. Infrared spectra for compounds 1 (a) and 2 (b) in the $2150-2200 \mathrm{~cm}^{-1}$ region, showing the principal bands that are temperature sensitive.

Both complexes, show a clear evolution of the $v(\mathrm{CN})$ modes with temperature, in agreement with the presence of the SCO: At $300 \mathrm{~K}$, complex 1 presents three strong vibration modes around 2063, 2070 and $2087 \mathrm{~cm}^{-1}$ (see Figure 3a, red band), while at $150 \mathrm{~K}$, corresponding to the $L S$ region (see Figure 2), three strong bands, characteristic of the $L S$ state, appear at higher wavenumbers (2109, 2112 and $2124 \mathrm{~cm}^{-1}$ ), in addition to the persistence of the three bands observed at $300 \mathrm{~K}$, but with lower intensities (Figure 3a, blue band). This spectrum confirms the predominance of the LS state at $150 \mathrm{~K}$ and the persistence at low temperature of the three weak HS characteristic bands, confirms the presence of a significant $H S$ fraction at $150 \mathrm{~K}$, in agreement with the magnetic studies.

For complex 2, the infrared spectrum at $500 \mathrm{~K}$ shows a large strong band around $2183 \mathrm{~cm}^{-1}$ characteristic of the HS spin state, in agreement with the magnetic studies (see Figure $3 \mathrm{~b}$, red band), while at $170 \mathrm{~K}$ a strong band appears around $2204 \mathrm{~cm}^{-1}$ (see Figure $3 \mathrm{~b}$, blue band) which should be attributed to the LS state as revealed by the magnetic studies. The temperature dependence of the infrared spectrum of complex 2 does not show significant persistence of the strong characteristic bands of the $H S$ state at low temperature, confirming the complete nature of the $H S$ to $L S$ transition in compound 2. 


\subsection{Magneto-Spectroscopic and Structural Relationships}

Based on the transition temperatures derived from the magnetic studies above and on the temperature regions of the SCO transition in $\mathbf{1}$ and $\mathbf{2}$, the crystal structure of $\mathbf{1}$ has been determined at 293 and $100 \mathrm{~K}$, corresponding, respectively to the HS and LS states; while the crystal structure of 2 has been only studied at $200 \mathrm{~K}$ to characterize the LS state since the HS state, expected above $500 \mathrm{~K}$, could not be reached by our single crystal X-ray equipment. However, this lack of high temperature structural data is compensated by the infrared studies performed in the temperature range $100-500 \mathrm{~K}$ since it is well known that the infrared spectroscopy is a very useful tool for the characterization of the $H S$ and LS states [37-43]. Therefore, the average value of the Fe-L distances (Fe-N) and the distortion parameter $(\Sigma)$ derived from the X-ray single crystal structural data [11-17,36], as well as the thermal evolution of the infrared vibration bands, which are highly sensitive to the Fe(II) spin state, will be used in this section to confirm the spin state on the Fe(II) centres.

Table 1 lists the average values of the Fe-N bond lengths and that of the $\Sigma$ and $\theta$ distortion parameters for all the Fe(II) centres of the three structures (structure of $\mathbf{1}$ at 293 and $100 \mathrm{~K}$, and structure of 2 at $200 \mathrm{~K})$. Similarly, it is noteworthy that each structure involves two iron(II) centres, the first one (Fe1), from the anionic complex $\left[\mathrm{Fe}\left(\mathrm{py}_{3} \mathrm{C}-\mathrm{OEt}\right)(\mathrm{NCE})_{3}\right]^{-}\left(\mathrm{E}=\mathrm{S}(\mathbf{1}), \mathrm{BH}_{3}(\mathbf{2})\right)$, and the second one $(\mathrm{Fe} 2)$ from the cationic complex $\left[\mathrm{Fe}\left(\mathrm{py}_{3} \mathrm{C}-\mathrm{OEt}\right)_{2}\right]^{2+}$. The average values of the $\mathrm{Fe}-\mathrm{N}\left(<\mathrm{d}_{(\mathrm{Fe}-\mathrm{N})}>\right)$ bonds of the coordination sphere of the cation (1.973(2) $\AA$ and 1.963(2) $\AA$ for 1 at 100 and $300 \mathrm{~K}$, respectively and $1.970(3) \AA$ for 2 at $200 \mathrm{~K}$ ) as well as the corresponding value of the $\left[\mathrm{Fe}\left(\mathrm{py}_{3} \mathrm{C}-\mathrm{OEt}\right)(\mathrm{NCS})_{3}\right]^{-}$anion in 1 at $100 \mathrm{~K}(1.958(3) \AA)$ are very similar and agree with the $L S$ state nature of the Fe2 centres in all cationic complexes and in the anionic unit of $\mathbf{1}$ at $100 \mathrm{~K}$, as also confirmed by the relatively low value of the $\Sigma$ distortion parameter (in the range 15.1-19.1 ${ }^{\circ}$ ) [11-26,29]. Thus, among all the metal centres, only the Fe1 ion from the anionic complex [Fe(py $\left.\left.{ }_{3} \mathrm{C}-\mathrm{OEt}\right)(\mathrm{NCS})_{3}\right]^{-}$of 1 at $293 \mathrm{~K}$ displays higher average $<\mathrm{d}_{(\mathrm{Fe}-\mathrm{N})}>$ value $(2.146(3) \AA)$ and more important distortion $\left(\Sigma=62.2^{\circ}, \theta=111.0^{\circ}\right)$ which are in good agreement with the corresponding values observed for the $H S \mathrm{Fe}(\mathrm{II})$ ion in a $\mathrm{FeN}_{6}$ distorted octahedral environment [11-17,24-33,36] and with the magnetic data.

The crystal structural characterization shows that the two complexes display discrete mononuclear structures which differ only in the three ancillary ligands (Figure 1). The overall crystal packing is assisted by intricate C-H $\cdots S$ hydrogen bonds for 1, which are very similar in compound 2 through $\mathrm{C}-\mathrm{H} \cdots \mathrm{B}$ interactions (Figure S8a), together with $\pi-\pi$ interactions between the $\left[\mathrm{Fe}\left(\mathrm{py}_{3} \mathrm{C}-\mathrm{OEt}\right)(\mathrm{NCE})_{3}\right]^{-}$ anionic complexes (Figure S8b). As shown in Figure S9, no significant strong intermolecular interactions are really dominant in the crystal packing, suggesting the absence of any significant cooperative effects as revealed by the gradual switching behaviours and the lack of hysteresis shown in Figure 2. However, the two compounds differ markedly by their overall transition temperatures since compound 1 exhibits a one-step transition centred at $205 \mathrm{~K}$; while complex 2 displays higher transition temperatures with a two-step behaviour at around $245 \mathrm{~K}$ and $380 \mathrm{~K}$. This observation led us to examine the Fe-N-CS bond angles in the two complexes. According to one of our recent experimental and theoretical magneto-structural work on SCO systems involving NCS units as ancillary co-ligands, some of us suggested that the bent configuration of the N-bound terminal thiocyanato ligand promotes a weaker ligand field on the Fe(II) ion than the linear one [32,33]. Examination of the Fe-N-CS angles summarized in Table 3 for the three crystal structures, clearly shows that the Fe-N-C(S) angles observed for complex 1 at $293 \mathrm{~K}$ present the higher deviation $\left(<\mathrm{Fe}-\mathrm{N}-\mathrm{C}>=166.7(4)^{\circ}\right)$ with respect to the linearity, with similar trend between the Fe-N-C(S) angles observed for 1 at $100 \mathrm{~K}\left(<\mathrm{Fe}-\mathrm{N}-\mathrm{C}>=171.7(3)^{\circ}\right)$ and the Fe-N-C(B) angles observed for 2 at $200 \mathrm{~K}\left(<\mathrm{Fe}-\mathrm{N}-\mathrm{C}>=174.0(4)^{\circ}\right)$. These structural observations suggest the following classification of the ligand field strength $(\mathbf{1}(H S, 293 \mathrm{~K})<\mathbf{1}(L S, 100 \mathrm{~K})<\mathbf{2}(L S, 200 \mathrm{~K}))[32,33]$, and confirms, as expected, that the ligand field is stronger in complex 2 involving the $\mathrm{NCBH}_{3}{ }^{-}$ancillary co-ligand, in agreement with its higher transition temperature derived from the magnetic studies [44]. 
Table 3. Fe-N-C bond angles $\left(^{\circ}\right)$ arising from the bent $\mathrm{N}$-bound terminal $\mathrm{kN}-\mathrm{ECN}$ coordination mode $\left(\mathrm{E}=\mathrm{S}(\mathbf{1}), \mathrm{BH}_{3}(\mathbf{2})\right)$.

\begin{tabular}{cccc}
\hline & \multicolumn{2}{c}{$\mathbf{1}$} & $\mathbf{2}$ \\
\hline & $\mathbf{2 9 3} \mathbf{K}$ & $\mathbf{1 0 0} \mathbf{K}$ & $\mathbf{2 0 0} \mathbf{K}$ \\
\hline Fe1-N1-C1 & $165.7(4)$ & $171.0(3)$ & $172.5(4)$ \\
Fe1-N2-C2 & $159.7(4)$ & $168.5(3)$ & $174.1(4)$ \\
Fe1-N3-C3 & $174.7(4)$ & $175.7(3)$ & $175.3(4)$ \\
\hline
\end{tabular}

As mentioned above, the infrared spectroscopy has been used in the present work to know more on the thermal evolution of the HS and LS state of both compounds. According to the chemical nature of the two compounds, their spin can be, in principle, studied using either stretching vibration of $\mathrm{NCS}$ and $\mathrm{NCBH}_{3}$ moieties or those of the Fe-N bonds. However, we have decided to focus our efforts on the thermal dependence of the infrared spectra of the stretching vibration of NCS and $\mathrm{NCBH}_{3}$ moieties (2150-2200 $\mathrm{cm}^{-1}$ in the case of complexes $\mathbf{1}$ and 2). That choice was justified by the fact that each compound is composed of two different $\mathrm{Fe}(\mathrm{II})$ complexes: $\left[\mathrm{Fe}\left(\mathrm{py}_{3} \mathrm{C}-\mathrm{OEt}\right)_{2}\right]^{2+}$ cationic complexes involving only $\mathrm{LS} \mathrm{Fe}(\mathrm{II})$ centres, and $\left[\mathrm{Fe}\left(\mathrm{py}_{3} \mathrm{C}-\mathrm{OEt}\right)(\mathrm{NCS})_{3}\right]^{-}\left(\mathrm{E}=\mathrm{S}(\mathbf{1})\right.$ and $\left.\mathrm{BH}_{3}(\mathbf{2})\right)$ anionic complexes exhibiting thermal spin transition; this should allow clearer discrimination of the three possible spin state configurations (HS or $L S$ single spin state, and HS/LS mixed spin state). Thus, for each compound, we have recorded the infrared spectra in the vicinity of the SCO transitions from 300 to $150 \mathrm{~K}$ for 1 (Figure 4a) and from 500 to $170 \mathrm{~K}$ for 2 (Figure $4 \mathrm{~b}$ ).

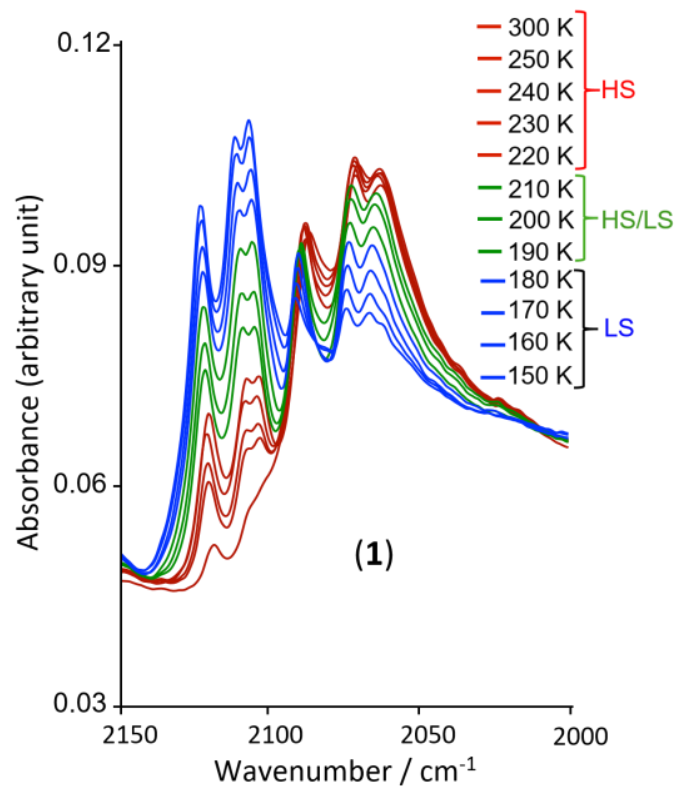

a)

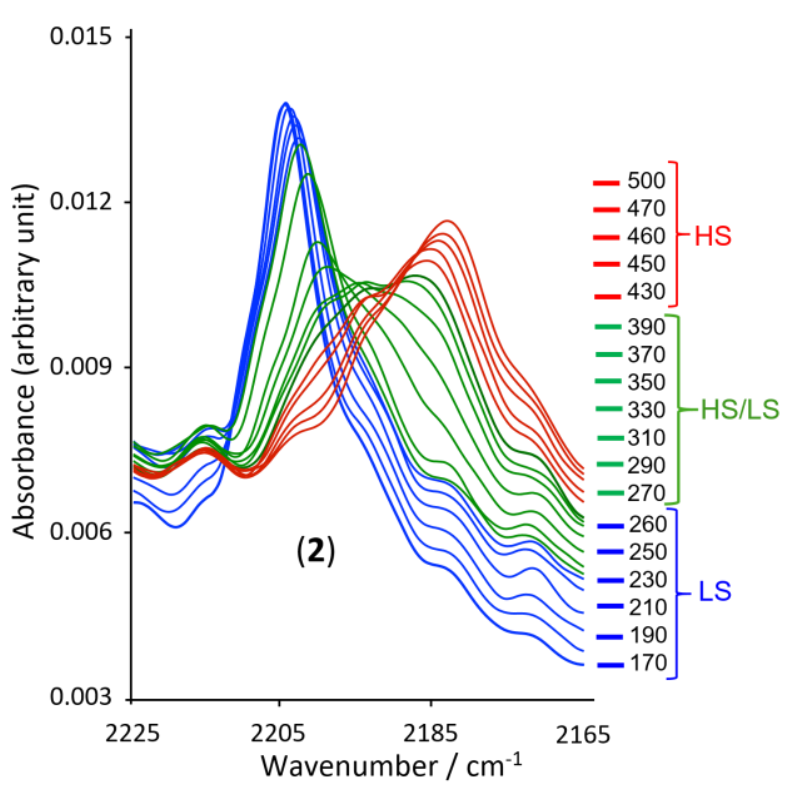

b)

Figure 4. Temperature dependences of the infrared spectra in the temperature region 300-150 K, for compound $\mathbf{1}$ (a) and in the temperature region $500-170 \mathrm{~K}$ for $\mathbf{2}$ (b).

For 1, the intensity of the three $v(\mathrm{NCS})$ vibrational bands observed at 2063,2070 and at $2087 \mathrm{~cm}^{-1}$, characteristic of the HS state, gradually decrease with decreasing the temperature from 300 to $150 \mathrm{~K}$. As discussed above, even at $150 \mathrm{~K}$, the three infrared bands persist (Figure $4 \mathrm{a}$ ), suggesting the presence of a residual Fe(II) HS state, in agreement with the magnetic studies. As the intensity decreases, three other bands, characteristic of the $L S$ state, appear at higher wavenumbers $\left(2109,2112\right.$ and $\left.2124 \mathrm{~cm}^{-1}\right)$ whose intensities gradually increase with decreasing the temperature. Similar trend was observed for the $v(\mathrm{NCB})$ vibrational bands of compound 2 (Figure $4 \mathrm{~b}$ ); the intensity of characteristic band of the $H S$ state, observed at $2183 \mathrm{~cm}^{-1}$, decreases with decreasing the temperature from 500 to $170 \mathrm{~K}$, while a new 
band, characteristic of the $L S$ state, appears at higher wavenumbers $\left(2204 \mathrm{~cm}^{-1}\right)$. To better assign each vibrational band to the corresponding spin state and to study the global consistency of the experimental data of the thermal dependence of the infrared spectroscopy in both compounds, we have correlated the results of the thermal dependence of the $\chi_{m} T$ product derived from magnetic measurements and those of the thermal evolution of the intensity of the infrared bands for both compounds. The data, summarized in Figure 5, show an excellent correlation between the thermal evolution of the $\chi_{m} T$ product and the intensity of one of the $H S$ characteristic bands $\left(2063 \mathrm{~cm}^{-1}\right.$ for 1 and $2183 \mathrm{~cm}^{-1}$ for 2$)$, showing a significant change in the temperature region where the thermal spin transition occurs in the magnetic data for both compounds.

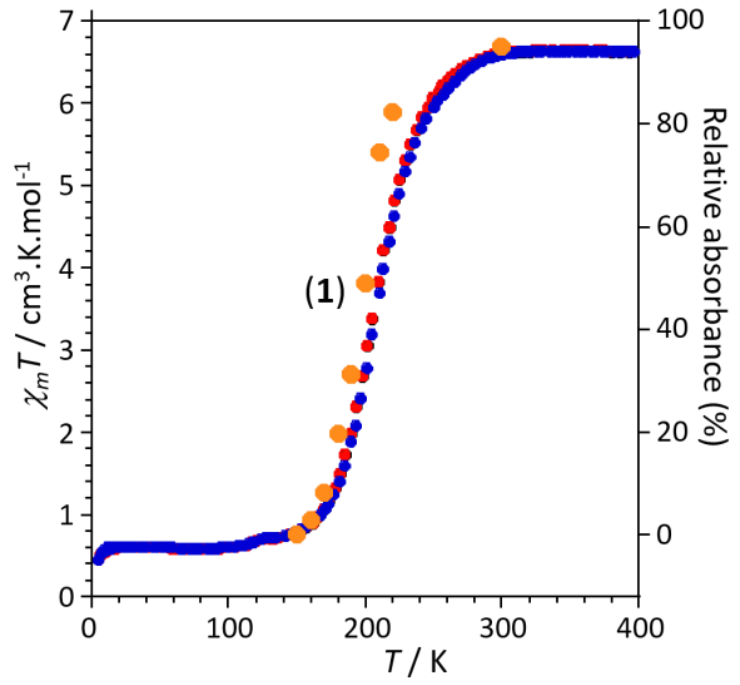

a)

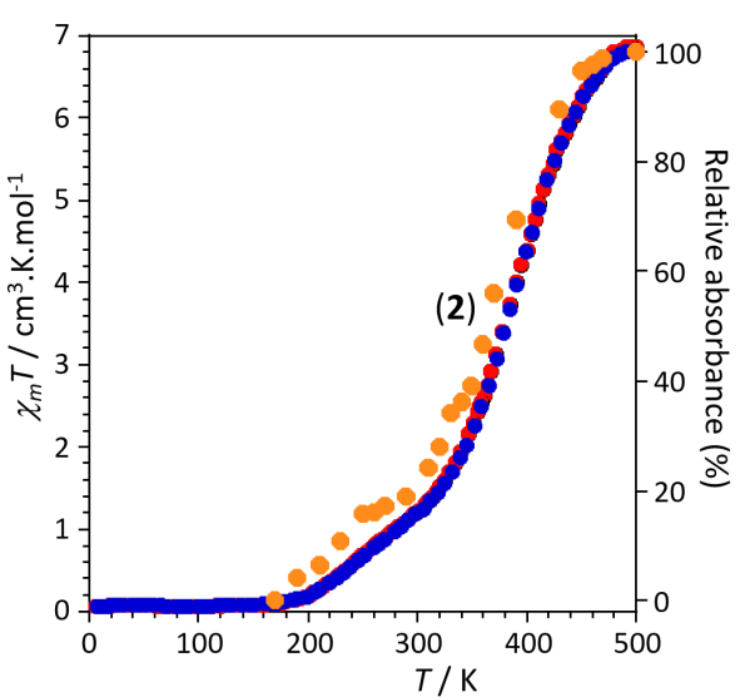

b)

Figure 5. (a) Temperature dependences of the $\chi_{m} T$ product and of the relative absorbance of the $v(\mathrm{CN})$ band observed at $2063 \mathrm{~cm}^{-1}(\bullet)$ for compound 1. (b) Temperature dependences of the $\chi_{m} T$ product and of the relative absorbance of the $v(\mathrm{CN})$ band observed at $2183 \mathrm{~cm}^{-1}(\bullet)$ for compound 2 .

Finally, it is important to note that one of the more intriguing observations in this contribution concerns the SCO behaviour observed for compound 2 that shows two-step transition centred around $245 \mathrm{~K}$ and $380 \mathrm{~K}$, while compound 1 exhibits a residual $\mathrm{HS}$ fraction of ca. 10\% below $150 \mathrm{~K}$. This unexpected behaviour was also confirmed by the temperature dependence of the infrared spectra as clearly shown in Figure $5 b$ for which the data derived from the infrared studies (thermal variation of the intensity of the infrared band observed at $2063 \mathrm{~cm}^{-1}$ ) perfectly fits with the two steps for 2 and the residual fraction for 1 revealed by the magnetic data.

Juxtaposition of the two-step behaviour (500-320 K and 320-200 K, see Figure 5b) of compound 2 with that observed for complex 1 in the temperature range of 260-160 K (see transition region in Figure 5a) reveals that the profile of the $\chi_{m} T$ vs. $T$ portion in the range $500-320 \mathrm{~K}$ (first step of 2) is close to that of $\mathbf{1}$ (see temperature range 260-100 K). Such juxtaposition, clearly depicted in Figure 6a, corresponds to that expected for two isomorph complexes for which the magnetic behaviours should only be differentiated by their transition temperatures, according to their ancillary co-ligands (NCS ${ }^{-}$ for 1 and $\mathrm{NCBH}_{3}{ }^{-}$for 2) that promotes different ligand field energies. We can therefore conclude that the first step observed for 2 in the range 500-320 K may be related to the isomorph crystal structures described above for both complexes, while the second step may be induced by unexpected structural changes. 


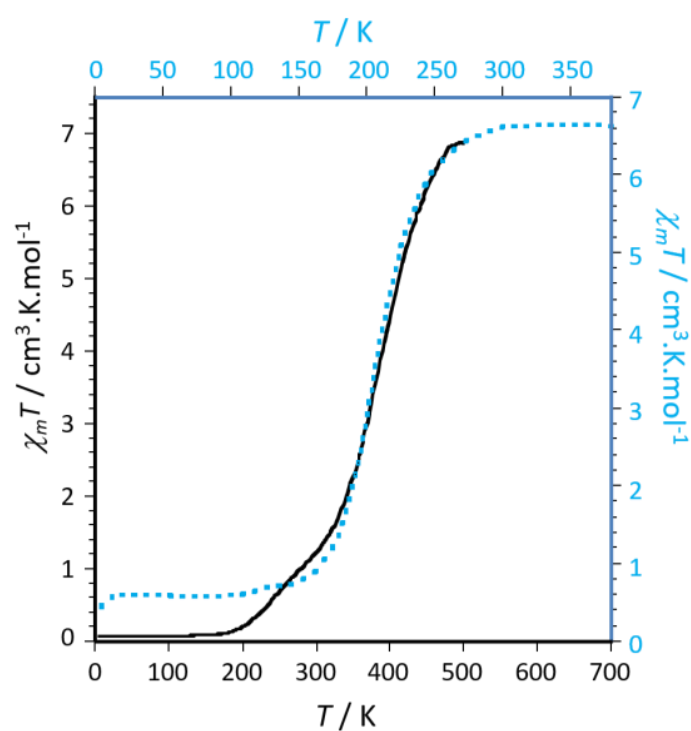

a)

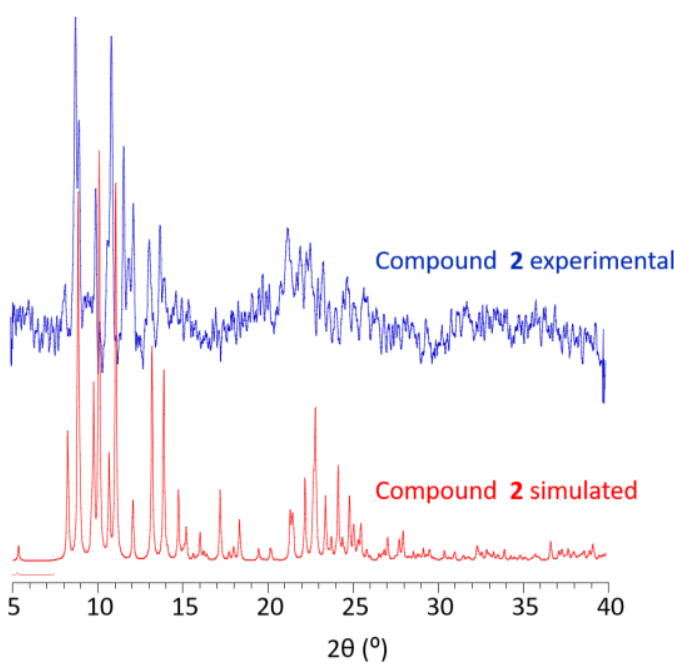

b)

Figure 6. (a) Temperature dependences of the $\chi_{m} T$ product of $\mathbf{1}$ (black solid line) and $\mathbf{2}$ (blue dashed line) showing similar behaviours above $320 \mathrm{~K}$, when the transition temperatures are not taken into account; (b) observed and calculated X-ray powder diffraction patterns for compound 2.

To shed light on the presence of such second step, we have performed additional X-ray experiments at room temperature near the centre of the second step observed for 2: (i) The single crystal structure could not be determined correctly at $293 \mathrm{~K}$ because of the low diffraction power of the single crystals due to the low crystallinity of the sample. This was confirmed by the powder X-ray diffraction recorded on crushed single crystals which does not give a well-resolved X-ray diffraction pattern (see Figure $6 \mathrm{~b}$ and Figure S10). The main diffraction peaks identified from the simulated diffraction pattern fits perfectly with the observed ones, while no other strong peaks are observed in the experimental pattern, which confirms first the purity of the powder sample and that no additional crystalline phase coexist, which could have corresponded to the second transition step. On the contrary, the observed diffraction pattern shows strong broad diffuse scattered signal, which is most probably the signature of an amorphous phase, which can be at the origin of to the second step. A different process is demonstrated by the powder X-ray diffraction for compound 1. In this case, the simulated and measured diffraction patterns match perfectly without any diffuse signal, ruling out the possibility of an additional amorphous phase. In that case, the residual fraction is present in the well crystalline phase, and contributes to the derived single crystal structure. As a matter of fact, the Fe-N and $<\mathrm{d}_{(\mathrm{Fe}-\mathrm{N})}>$ bond distances are systematically slightly higher for compound $\mathbf{1}$ at $100 \mathrm{~K}$, by comparison with compound 2 at $200 \mathrm{~K}$ (see Table 2).

\section{Experimental Section}

\subsection{Starting Materials}

Organic starting compounds, iron salts, and solvents were purchased from Sigma-Aldrich and Acros Organic. Deuterated solvents were purchased from Cambridge Isotope Laboratories. Dried solvents were prepared by refluxing for one day under nitrogen over appropriate drying agents (sodium and benzophenone for tetrahydrofuran (THF), calcium hydride for methanol, barium oxide under vacuum for dimethylformamide (DMF), sodium for ethanol), others solvents used were dried through drying column. All the ligand syntheses were carried out under nitrogen atmosphere by using a dual manifold vacuum/nitrogen line and standard Schlenk techniques. 


\subsection{Syntheses of Tris(pyridin-2-yl)methanol $\left(p y_{3} C-O H\right)$ and Tris(pyridin-2-yl)ethoxymethane ( $\left.p y_{3} C-O E t\right)$}

The syntheses were performed following the previous published procedures [34,35] with slight modifications which induce more significant yields.

\subsubsection{Synthesis of Tris(pyridin-2-yl)methanol ( $\left.\mathrm{py}_{3} \mathrm{C}-\mathrm{OH}\right)$}

A solution containing 2-bromopyridine $(6.32 \mathrm{~g} ; 3.8 \mathrm{~mL} ; 40.0 \mathrm{mmol})$ and $50 \mathrm{~mL}$ of distilled THF was cooled to $-80^{\circ} \mathrm{C}$ under nitrogen atmosphere. Then $\mathrm{n}-\mathrm{BuLi}(20.0 \mathrm{~mL}, 50.0 \mathrm{mmol})$ was added dropwise leading to a bright red solution. After stirring for $15 \mathrm{~min}$ at $-80^{\circ} \mathrm{C}$, a solution of $2,2^{\prime}$-dipyridyl ketone (7.36 g, $40.0 \mathrm{mmol})$, which was dissolved beforehand in $50 \mathrm{~mL}$ of THF, was slowly added to avoid an increase of the temperature. The resulting marine blue solution was then stirred at $-80{ }^{\circ} \mathrm{C}$ until the coloration became deep purple, and stirred again for $2 \mathrm{~h}$ at room temperature (see Scheme S1). The reaction was quenched with $30 \mathrm{~mL}$ methanol, and warmed to room temperature. The final solution was filtered to remove the white precipitate and $100 \mathrm{~mL}$ of water was added. The aqueous phase was extracted with $200 \mathrm{~mL}$ of dichloromethane, dried over magnesium sulfate, and evaporated using a rotary evaporator. The brown oil resulting compound was purified using $5 \mathrm{~mL}$ of acetone and left in the freezer overnight at $-28{ }^{\circ} \mathrm{C}$, to obtain a white powder $(9.26 \mathrm{~g}, 35.2 \mathrm{mmol}$, yield $88 \%)$. ${ }^{1} \mathrm{H} \mathrm{NMR}$ $\left(\mathrm{CDCl}_{3}, 400 \mathrm{MHz}, \delta(\mathrm{ppm})\right)$ of $\mathrm{py}_{3} \mathrm{C}-\mathrm{OH}$ at $25^{\circ} \mathrm{C}: 7.20(3 \mathrm{H}, \mathrm{CH}$ aromatic, q, 3JH-H = $5 \mathrm{~Hz}, \mathrm{H3}), 7.68$ $(3 \mathrm{H}, \mathrm{CH}$ aromatic, td, H4), $7.75(3 \mathrm{H}, \mathrm{CH}$ aromatic, q, 3JH-H $=8 \mathrm{~Hz}, \mathrm{H} 5), 8.46(3 \mathrm{H}, \mathrm{CH}$ aromatic, $3 \mathrm{JH}-\mathrm{H}=5 \mathrm{~Hz}, \mathrm{td}, \mathrm{H} 2) .{ }^{13} \mathrm{C} \mathrm{NMR}\left(\mathrm{CDCl}_{3}, 75 \mathrm{MHz}, \delta(\mathrm{ppm})\right)$ of $\mathrm{py}_{3} \mathrm{COH}$ at $25{ }^{\circ} \mathrm{C}: 81.27(\mathrm{C} 7), 121.36$ (C3), 122.01 (C5) 135.46 (C4), 146.87 (C2), 161.99 (C6).

\subsubsection{Synthesis Tris(pyridin-2-yl)ethoxymethane $\left(\mathrm{py}_{3} \mathrm{C}-\mathrm{OEt}\right)$}

Under Nitrogen atmosphere, in a $50 \mathrm{~mL}$ flask was dissolved tris(pyridyl)methanol (400 mg, $1.52 \mathrm{mmol}$ ) in $4 \mathrm{~mL}$ of distilled $N, N^{\prime}$-dimethylformamide. Then sodium hydride was quickly and carefully added $(180 \mathrm{mg}, 7.50 \mathrm{mmol})$ and the mixture was stirred for $30 \mathrm{~min}$ at $0{ }^{\circ} \mathrm{C}$ before adding dropwise 1-iodoethane $(249 \mathrm{mg}, 165 \mu \mathrm{L}, 1.60 \mathrm{mmol})$. After stirring for $5 \mathrm{~h}$ at room temperature, the reaction was quenched with $20 \mathrm{~mL}$ of acetone/methanol (1:1) solution (see Scheme S2). Then a volume of $10 \mathrm{~mL}$ of water was added before evaporating the organic phase with a rotary evaporator. The crude product was extracted with dichloromethane and purified in a 1:4 mixture of acetone: Pentane, one night in the freezer. The molecule was obtained as a white powder $(375 \mathrm{mg}, 1.2 \mathrm{mmol}$, $85 \%) .{ }^{1} \mathrm{H} \mathrm{NMR}(\mathrm{CDCl} 3,400 \mathrm{MHz}, \delta(\mathrm{ppm}))$ of py $3 \mathrm{C}-\mathrm{OEt}$ at $25{ }^{\circ} \mathrm{C}: 1.24(3 \mathrm{H}, \mathrm{CH} 3, \mathrm{t}, 3 \mathrm{JH}-\mathrm{H}=7.2 \mathrm{~Hz}$, $\mathrm{H} 10), 3.37$ (2H, CH2, q, 3JH-H= 7.2 Hz, H9), $7.13(3 \mathrm{H}, \mathrm{CH}$ aromatic ring, q, 3JH-H = $8 \mathrm{~Hz}, \mathrm{H3}), 7.65$ $(3 \mathrm{H}, \mathrm{CH}$ aromatic ring, q, 3JH-H = $8 \mathrm{~Hz}, \mathrm{H} 5), 7.73(3 \mathrm{H}, \mathrm{CH}$ aromatic ring, d, 3JH-H = $8 \mathrm{~Hz}, \mathrm{H} 4), 8.57$ $(2 \mathrm{H}, \mathrm{CH}$ aromatic ring, d, 3JH-H $=4.8 \mathrm{~Hz}, \mathrm{H} 2) .{ }^{13} \mathrm{C} \mathrm{NMR}(\mathrm{CDCl} 3,125 \mathrm{MHz}, \delta(\mathrm{ppm}))$ of py ${ }_{3} \mathrm{C}-\mathrm{OEt}$ at $25^{\circ} \mathrm{C}: 15.56$ (C10), 60.67 (C9), 88.11 (C7), 122.03 (C3), 123.61 (C5) 136.16 (C4), 148.63 (C2), 161.84 (C6).

\subsection{Synthesis of $\left[\mathrm{Fe}\left(p y_{3} \mathrm{C}-\mathrm{OEt}\right)_{2}\right]\left[\mathrm{Fe}\left(p y_{3} \mathrm{C}-\mathrm{OEt}\right)(\mathrm{NCE})_{3}\right]_{2} \cdot 2 \mathrm{CH}_{3} \mathrm{CN}\left(\mathrm{E}=\mathrm{S}(1), \mathrm{NCBH}_{3}(2)\right)$}

In $5 \mathrm{~mL}$ of distilled methanol were dissolved tri(pyridin-2-yl)ethoxymethane $(50.0 \mathrm{mg}, 0.17 \mathrm{mmol})$, iron(II) chloride salt $(20.0 \mathrm{mg}, 0.16 \mathrm{mmol})$ and a few $\mathrm{mg}$ of ascorbic acid. The resulting solution was stirred for $15 \mathrm{~min}$ at room temperature and then a solution of acetonitrile $(5 \mathrm{~mL})$ containing $0.69 \mathrm{mmol}$ of $\left(\mathrm{C}_{2} \mathrm{H}_{5} \mathrm{~N}\right)$ (NCE) was added. The resulting solution was stirred for $30 \mathrm{~min}$ and then filtered and placed quickly at $-32{ }^{\circ} \mathrm{C}$. After a few days, orange and red prismatic single crystals of $\mathbf{1}$ and 2 , respectively, were recovered. Anal. Calcd. (\%) for $\left[\mathrm{Fe}\left(\mathrm{py}_{3} \mathrm{C}-\mathrm{OEt}\right)_{2}\right]\left[\mathrm{Fe}\left(\mathrm{py}{ }_{3} \mathrm{C}-\mathrm{OEt}\right)(\mathrm{NCS})_{3}\right]_{2} \cdot 2 \mathrm{CH} \mathrm{H}_{3} \mathrm{CN}$ $\left(\mathrm{C}_{82} \mathrm{H}_{74} \mathrm{Fe}_{3} \mathrm{~N}_{20} \mathrm{O}_{4} \mathrm{~S}_{6}\right), 1: \mathrm{C}, 55.8 ; \mathrm{H}, 4.2 ; \mathrm{N}, 15.9$; Found (\%): C, 55.4; H, 4.0; N, 15.3. IR data $\left(\mathrm{v} / \mathrm{cm}^{-1}\right)$ for the freshly filtered sample: 410w, 423w, 477w, 500w, 513w, 530w, 659m, 726w, 758w, 886w, 1011m, 1086w, 1108m, 1143m, 1205w, 1252w, 1291w, 1389w, 1434m, 1462s, 1593m, 2060s, 2244w, 2871w, 2901w, 2972.11w, 3076w, 3442br. Anal. Calcd. (\%) for [Fe(py $\left.\left.{ }_{3} \mathrm{C}-\mathrm{OEt}\right)_{2}\right]\left[\mathrm{Fe}\left(\mathrm{py}_{3} \mathrm{C}-\mathrm{OEt}\right)\left(\mathrm{NCBH}_{3}\right)_{3}\right]_{2} \cdot 2 \mathrm{CH} \mathrm{CN}_{3} \mathrm{CN}$ $\left(\mathrm{C}_{82} \mathrm{H}_{92} \mathrm{Fe}_{3} \mathrm{~N}_{20} \mathrm{O}_{4} \mathrm{~B}_{6}\right)$, 2: C, 59.4; $\mathrm{H}, 5.6 ; \mathrm{N} ; 16.9$. Found (\%): C, 59.0; H, 5.4; N, 16.3. IR data $\left(v / \mathrm{cm}^{-1}\right)$ for the freshly filtered sample: 467w, 491w, 481w, 512m, 530m, 558w, 591w, 616w, 684w, 743w, 759s, 774s, 
798s, 863m, 871m, 890w, 900w, 946w, 1012 m, 1067w, 1087s, 1109w, 1123s, 1135w, 1142m, 1163s, 1205m, 1248w, 1298m, 1394w, 1439s, 1460s, 1595m, 2168m, 2219w, 2312s 2329m, 2919w, 2982w, 3071w), 3105w.

\subsection{Characterization of the Materials}

Elemental analyses were performed by the "Service Central d'Analyses du CNRS", Gif-sur-Yvette, France. Room temperature infrared spectra of ligands and complexes were recorded on a platinum ATR Vertex 70 BRUKER spectrometer in the range $4000-400 \mathrm{~cm}^{-1}$. ${ }^{1} \mathrm{H}$ et ${ }^{13} \mathrm{C}$ NMR spectra were recorded using BRUKER DRX $300 \mathrm{MHz}$, Advance $400 \mathrm{MHz}$ and Advance III HD $500 \mathrm{MHz}$ equipment (University of Brest). All chemical shifts are defined in ppm and determined by using the rightful deuterated solvent as a reference.

\subsection{Magnetic Measurements}

Magnetic susceptibility measurements were carried out in the temperature range $2-400 \mathrm{~K}$ for $\mathbf{1}$ and in the range $2-500 \mathrm{~K}$ for 2 with an applied magnetic field of $0.1 \mathrm{~T}$, on polycrystalline samples of both compounds (with masses of $11.634 \mathrm{mg}$ for 1 and $4.065 \mathrm{mg}$ for 2) with a Quantum Design MPMS-XL-5 SQUID susceptometer (San Diego, CA, USA) using a sample space oven for compound 2 (in the range $300-500 \mathrm{~K})$. Consecutive cooling and warming scans at a scan rate of $2 \mathrm{~K} \mathrm{~min}^{-1}$ showed identical behaviours without any noticeable hysteresis. The susceptibility data were corrected for the sample holders previously measured using the same conditions and for the diamagnetic contributions of the salt as deduced by using Pascal's constant tables [45]. The photomagnetic studies were performed by cooling the samples down to $10 \mathrm{~K}$ at a rate of $1 \mathrm{~K} \mathrm{~min}^{-1}$ and then irradiating them with a green Diode Pumped Solid State Laser DPSS-532-20 from Chylas $(\lambda=532 \mathrm{~nm}$, power $=20 \mathrm{~mW})$ coupled via an optical fibre to the cavity of the SQUID magnetometer.

\subsection{Crystallographic Data Collection and Refinement}

The crystallographic studies were performed at room temperature and at $100 \mathrm{~K}$ for $\mathbf{1}$, and at $200 \mathrm{~K}$ for 2, using an Oxford Diffraction Xcalibur K-CCD diffractometer equipped with a graphite monochromated MoK $\alpha$ radiation $(\lambda=0.71073 \AA)$. The full sphere data collections were performed using $1.0^{\circ} \omega$-scans with different exposure times per frame $(225 \mathrm{~s}$ for $\mathbf{1}$ at $293 \mathrm{~K}, 45 \mathrm{~s}$ for $\mathbf{1}$ at $100 \mathrm{~K}$, and $175 \mathrm{~s}$ for 2 at $200 \mathrm{~K}$ ). Data collection and data reduction were done with the CRYSALIS-CCD and CRYSALIS-RED programs on the full set of data [46]. The crystal structures were solved by direct methods and successive Fourier difference syntheses, and were refined on $F^{2}$ by weighted anisotropic full-matrix least-square methods [47]. All non-hydrogen atoms were refined anisotropically and the hydrogen atoms were calculated and included as isotropic fixed contributors to $F_{\mathrm{c}}$. All other calculations were performed with standard procedures (OLEX2) [48]. Crystal data, structure refinement, and collection parameters are listed in Table 1.

X-ray powder diffraction (XRPD) data were collected for both compounds on polycrystalline samples filled into $0.7 \mathrm{~mm}$ glass capillaries that were mounted and aligned on a Empyrean PANalytical powder diffractometer, at $45 \mathrm{kV}, 40 \mathrm{~mA}$ using $\mathrm{Cu} \mathrm{K} \alpha$ radiation $(\lambda=1.54177 \AA)$. A total of four scans were collected for each sample, at room temperature in the $2 \theta$ range of $5-40^{\circ}$. The isostructurality of the samples prepared was confirmed with the experimental and simulated powder X-ray diffractograms (Figure S10).

CCDC-1998534-1998536 contains the supplementary crystallographic data for compounds 1 (293 K and $100 \mathrm{~K}$ ) and $2(200 \mathrm{~K})$, respectively. These data can be obtained free of charge from The Cambridge Crystallographic Data Center at www.ccdc.cam.ac.uk/data_request/cif.

\section{Conclusions}

Two novel SCO Fe(II) complexes: $\left[\mathrm{Fe}\left(\mathrm{py}_{3} \mathrm{C}-\mathrm{OEt}\right)_{2}\right]\left[\mathrm{Fe}\left(\mathrm{py}_{3} \mathrm{C}-\mathrm{OEt}\right)(\mathrm{NCE})_{3}\right]_{2} \cdot 2 \mathrm{CH}_{3} \mathrm{CN}$, with $\mathrm{E}=\mathrm{S}(\mathbf{1})$, $\mathrm{NCBH}_{3}(2)$, based on the tris(2-pyridyl)ethoxymethane (py ${ }_{3} \mathrm{C}-\mathrm{OEt}$ ) tripodal ligand and the two ancillary $\mathrm{NCS}^{-}$and $\mathrm{NCBH}_{3}{ }^{-}$co-ligands, have been prepared. Complex $\mathbf{1}$ has been structurally characterized 
at room temperature $(293 \mathrm{~K})$ and at $100 \mathrm{~K}$, while complex 2 has been only characterized at $200 \mathrm{~K}$. Both compounds display almost similar molecular structures composed by similar cationic complex $\left(\left[\mathrm{Fe}\left(\mathrm{py}_{3} \mathrm{C}-\mathrm{OEt}\right)_{2}\right]^{2+}\right)$ and anionic complex $\left(\left[\mathrm{Fe}\left(\mathrm{py}_{3} \mathrm{C}-\mathrm{OEt}\right)(\mathrm{NCE})_{3}\right]^{-}\right.$, with $\left.\mathrm{E}=\mathrm{S}(\mathbf{1}), \mathrm{NCBH}_{3}(2)\right)$. Even if they display isomorph crystallographic structures, the magnetic studies revealed two different SCO behaviours without hysteretic effects: For complex 1, the thermal variation of the $\chi_{m} \mathrm{~T}$ product showed an incomplete gradual HS-LS transition at $\mathrm{T}_{1 / 2}=205 \mathrm{~K}$ with residual fraction of the HS spin of $c a$. $10 \%$., while complex 2 exhibits a complete and gradual HS to LS two-step-like transition centred around $245 \mathrm{~K}$ and $380 \mathrm{~K}$. These magnetic data are in good agreement with the variable temperature infrared spectroscopy performed in the $2150-2200 \mathrm{~cm}^{-1}$ range corresponding to the fundamental stretching vibration of $\mathrm{NCS}(\mathbf{1})$ and $\mathrm{NCBH}_{3}$ (2) moieties. Furthermore, the thermal dependence of the intensity of the stretching vibration of NCS and $\mathrm{NCBH}_{3}$ moieties $\left(2150-220 \mathrm{~cm}^{-1}\right.$ in the case of complexes 1 and 2 ) showed a clear correlation, including the intriguing two-step behaviour for complex 2 , with the thermal dependences of the $\chi_{\mathrm{m}} \mathrm{T}$ product derived from magnetic measurements for each complex. Finally, additional X-ray experiments at room temperature, where the second step of $\mathbf{2}$ is centred, revealed low diffraction power probably due to the low crystallinity of the sample, in agreement with the powder X-ray diffraction recorded on crushed single crystals that show a low crystallinity diffraction pattern.

Supplementary Materials: The following are available online at http:/www.mdpi.com/2312-7481/6/ 2/26/s1, Scheme S1: Synthesis of tris(pyridin-2-yl)methanol (py, $\mathrm{C}-\mathrm{OH})$, Scheme S2: Synthesis of tris(pyridin-2-yl)ethoxymethane (py $\left.{ }_{3} \mathrm{C}-\mathrm{OEt}\right)$, Figure S1: ${ }^{1} \mathrm{H} \mathrm{NMR}\left(\mathrm{CDCl}_{3}, 400 \mathrm{MHz}, \delta(\mathrm{ppm})\right.$ ) of py $\mathrm{C}_{3} \mathrm{OH}$ at $25^{\circ} \mathrm{C}$, Figure S2: ${ }^{13} \mathrm{C} \mathrm{NMR}\left(\mathrm{CDCl}_{3}, 75 \mathrm{MHz}, \delta(\mathrm{ppm})\right)$ of $\mathrm{py}_{3} \mathrm{C}-\mathrm{OH}$ at $25^{\circ} \mathrm{C}$, Figure S3: IR spectrum of py ${ }_{3} \mathrm{C}-\mathrm{OH}$ at $25{ }^{\circ} \mathrm{C}$, Figure S4: ${ }^{1} \mathrm{H} \mathrm{NMR}(\mathrm{CDCl} 3,400 \mathrm{MHz}, \delta(\mathrm{ppm}))$ of py ${ }_{3} \mathrm{C}-\mathrm{OEt}$ at $25 \mathrm{C}$, Figure S5: ${ }^{13} \mathrm{C} \mathrm{NMR}(\mathrm{CDCl} 3,125$ $\mathrm{MHz}, \delta(\mathrm{ppm}))$ of $\mathrm{py}_{3} \mathrm{C}-\mathrm{OEt}$ at $25^{\circ} \mathrm{C}$, Figure S6: IR of py ${ }_{3} \mathrm{C}-\mathrm{OEt}$ at $25^{\circ} \mathrm{C}$, Figure S7: Molecular structure of 1-2 showing the asymmetric unit and the $\mathrm{Fe}(\mathrm{II})$ environments of the anionic $\left(\left[\mathrm{Fe}\left(\mathrm{py}_{3} \mathrm{C}-\mathrm{OEt}\right)(\mathrm{NCE})_{3}\right]^{-}\right)$and cationic $\left(\left[\mathrm{Fe}\left(\mathrm{py}_{3} \mathrm{C}-\mathrm{OEt}\right)_{2}\right]^{2+}\right)$ moieties, Figure S8: Projection of the crystal packing in the $a c$ plane (a) and $\pi-\pi$ contact motif (b) of $\mathbf{1}$ (similar in 2), Figure S9: 3D Hirshfeld surface maps and fingerprint plots of the intermolecular interactions around the $\left[\mathrm{Fe}\left(\mathrm{py}_{3} \mathrm{C}-\mathrm{OEt}\right)(\mathrm{NCE})_{3}\right]^{-}$anions for compounds $\mathbf{1}$ and 2, Figure S10: Experimental and simulated XRPD patterns for compounds 1 and 2, Table S1: Crystal data and structural refinement parameters for complexes $\left[\mathrm{Fe}\left(\mathrm{py}_{3} \mathrm{C}-\mathrm{OEt}\right)_{2}\right]\left[\mathrm{Fe}\left(\mathrm{py}_{3} \mathrm{C}-\mathrm{OEt}\right)(\mathrm{NCE})_{3}\right]_{2} \cdot 2 \mathrm{CH}_{3} \mathrm{CN}\left(\mathrm{E}=\mathrm{S}(\mathbf{1}), \mathrm{BH}_{3}(2)\right)$, Table S2: Bond lengths and bond angles of compounds 1 and 2 .

Author Contributions: E.C. synthesized the ligand and the complexes with supervision of S.T.; and recorded and analyzed the infrared spectra with supervision of N.C. and S.P.; F.C. supervised the organic syntheses and interpreted the NMR spectra; E.C. analyzed the crystal data of the metal complexes with supervision of S.P.; S.B. performed the X-ray power diffraction and helped with the single crystal structures determination; C.J.G.-G. performed and interpreted the magnetic measurements; S.T. supervised the experimental work and wrote the manuscript on which all the authors have contributed. All authors have read and agreed to the published version of the manuscript.

Funding: This research was funded by the French CNRS (MITI Project), the "Universite de Brest" (IBSAM institute), the Région Bretagne (EC), the Generalidad Valenciana (Prometeo2019/076 project) and the Spanish MINECO (Project CTQ2017-87201-P AEI/FEDER, EU).

Conflicts of Interest: The authors declare no conflict of interest.

\section{References}

1. Kumar, K.S.; Ruben, M. Emerging trends in spin crossover (SCO) based functional materials and devices. Coord. Chem. Rev. 2017, 346, 176-205. [CrossRef]

2. Matsuda, M.; Isozaki, H.; Tajima, H. Reproducible on-off switching of the light emission from the electroluminescent device containing a spin crossover complex. Thin Solid Films 2008, 517, 1465-1467. [CrossRef]

3. Benaicha, B.; Van Do, K.; Yangui, A.; Pittala, N.; Lusson, A.; Sy, M.; Bouchez, G.; Fourati, H.; Gómez-García, C.J.; Triki, S.; et al. Interplay between Spin-Crossover and Luminescence in a Multifunctional Single Crystal Iron (II) complex: Towards a New Generation of Molecular Sensors. Chem. Sci. 2019, 10, 6791-6798. [CrossRef] [PubMed]

4. Paraïso, T.K.; Wouters, M.; Léger, Y.; Morier-Genoud, F.; Deveaud-Plédran, B. Multistability of a coherent spin ensemble in a semiconductor microcavity. Nat. Mater. 2010, 9, 655-660. [CrossRef] [PubMed] 
5. Coronado, E.; Galán-Mascarós, J.R.; Monrabal-Capilla, M.; García-Martínez, J.; Pardo-Ibáñez, P. Bistable Spin-Crossover Nanoparticles Showing Magnetic Thermal Hysteresis near Room Temperature. Adv. Mater. 2007, 19, 1359-1361. [CrossRef]

6. Sato, O. Dynamic molecular crystals with switchable physical properties. Nat. Chem. 2016, 8, $644-656$. [CrossRef]

7. Shalabaeva, V.; Ridier, K.; Rat, S.; Manrique-Juarez, M.D.; Salmon, L.; Séguy, I.; Rotaru, A.; Molnár, G.; Bousseksou, A. Room temperature current modulation in large area electronic junctions of spin crossover thin films. Appl. Phys. Lett. 2018, 112, 013301. [CrossRef]

8. Dugay, J.; Giménez-Marqués, M.; Kozlova, T.; Zandbergen, H.W.; Coronado, E.; van der Zant, H.S.J. Spin Switching in Electronic Devices Based on 2D Assemblies of Spin-Crossover Nanoparticles. Adv. Mater. 2015, 27, 1288-1293. [CrossRef]

9. Prins, F.; Monrabal-Capilla, M.; Osorio, E.A.; Coronado, E.; van der Zant, H.S.J. Room-Temperature Electrical Addressing of a Bistable Spin-Crossover Molecular System. Adv. Mater. 2011, 23, 1545-1549. [CrossRef]

10. Rueckes, T.; Kim, K.; Joselevich, E.; Tseng, G.Y.; Cheung, C.-L.; Lieber, C.M. Carbon Nanotube-Based Nonvolatile Random Access Memory for Molecular Computing. Science 2000, 289, 94-97. [CrossRef]

11. Halcrow, M.A. (Ed.) Spin-Crossover Materials, Properties and Applications; John Wiley \& Sons Ltd.: Oxford, UK, 2013.

12. Pittala, N.; Thétiot, F.; Triki, S.; Boukheddaden, K.; Chastanet, G.; Marchivie, M. Cooperative 1D Triazole-Based Spin Crossover Fe ${ }^{\mathrm{II}}$ Material with Exceptional Mechanical Resilience. Chem. Mater. 2017, 29, 490-494. [CrossRef]

13. Phan, H.; Hrudka, J.J.; Igimbayeva, D.; Lawson Daku, L.M.; Shatruk, M. A Simple Approach for Predicting the Spin State of Homoleptic Fe(II) Tris-diimine Complexes. J. Am. Chem. Soc. 2017, 139, 6437-6447. [CrossRef] [PubMed]

14. Pittala, N.; Thétiot, F.; Charles, C.; Triki, S.; Boukheddaden, K.; Chastanet, G.; Marchivie, M. An unprecedented trinuclear $\mathrm{Fe}^{\mathrm{II}}$ triazole-based complex exhibiting a concerted and complete sharp spin transition above room temperature. Chem. Commun. 2017, 53, 8356-8359. [CrossRef] [PubMed]

15. Milin, E.; Patinec, V.; Triki, S.; Bendeif, E.-E.; Pillet, S.; Marchivie, M.; Chastanet, G.; Boukheddaden, K. Elastic Frustration Triggering Photoinduced Hidden Hysteresis and Multistability in a Two-Dimensional Photoswitchable Hofmann-Like Spin-Crossover Metal-Organic Framework. Inorg. Chem. 2016, 55, 11652-11661. [CrossRef] [PubMed]

16. Shatruk, M.; Phan, H.; Chrisostomo, B.A.; Suleimenova, A. Symmetry-breaking structural phase transitions in spin crossover complexes. Coord. Chem. Rev. 2015, 289-290, 62-73. [CrossRef]

17. Atmani, A.; El Hajj, F.; Benmansour, S.; Marchivie, M.; Triki, S.; Conan, F.; Patinec, V.; Handel, H.; Dupouy, G.; Gómez-García, C.J. Guidelines to design new spin crossover materials. Coord. Chem. Rev. 2010, 254, 1559-1569. [CrossRef]

18. Phonsri, W.; Macedo, D.S.; Lewis, B.A.I.; Wain, D.F.; Murray, K.S. Iron(III) Azadiphenolate Compounds in a New Family of Spin Crossover Iron(II)-Iron(III) Mixed-Valent Complexes. Magnetochemistry 2019, 5, 37. [CrossRef]

19. Floquet, S.; Boillot, M.-L.; Rivière, E.; Varret, F.; Boukheddaden, K.; Morineau, D.; Négrier, P. Spin transition with a large thermal hysteresis near room temperature in a water solvate of an iron(III) thiosemicarbazone complex. New J. Chem. 2003, 27, 341-348. [CrossRef]

20. Floquet, S.; Guillou, N.; Négrier, P.; Rivière, E.; Boillot, M.-L. The crystallographic phase transition for a ferric thiosemicarbazone spin crossover complex studied by X-ray powder diffraction. New J. Chem. 2006, 30, 1621-1627. [CrossRef]

21. Cook, C.; Habib, F.; Aharen, T.; Clérac, R.; Hu, A.; Murugesu, M. High-Temperature Spin Crossover Behavior in a Nitrogen-Rich Fe ${ }^{\mathrm{III}}$ Based System. Inorg. Chem. 2013, 52, 1825-1831. [CrossRef]

22. Takahashi, K.; Kawamukai, K.; Okai, M.; Mochida, T.; Sakurai, T.; Ohta, H.; Yamamoto, T.; Einaga, Y.; Shiota, Y.; Yoshizawa, K. A New Family of Anionic Fe ${ }^{\mathrm{III}}$ Spin Crossover Complexes Featuring a Weak-Field $\mathrm{N}_{2} \mathrm{O}_{4}$ Coordination Octahedron. Chem. Eur. J. 2016, 22, 1253-1257. [CrossRef] [PubMed]

23. Phonsri, W.; Lewis, B.A.I.; Jameson, G.N.L.; Murray, K.S. Double spin crossovers: A new double salt strategy to improve magnetic and memory properties. Chem. Commun. 2019, 55, 14031-14034. [CrossRef] [PubMed] 
24. Yamada, M.; Ooidemizu, M.; Ikuta, Y.; Osa, S.; Matsumoto, N.; Iijima, S.; Kojima, M.; Dahan, F.; Tuchagues, J.-P. Interlayer Interaction of Two-Dimensional Layered Spin Crossover Complexes $\left[\mathrm{Fe}^{\mathrm{II}} \mathrm{H}_{3} \mathrm{~L}^{\mathrm{Me}}\right]\left[\mathrm{Fe}^{\mathrm{II}} \mathrm{L}^{\mathrm{Me}}\right] \mathrm{X}\left(\mathrm{X}^{-}=\mathrm{ClO}_{4}{ }^{-}, \mathrm{BF}_{4}{ }^{-}, \mathrm{PF}_{6}{ }^{-}, \mathrm{AsF}_{6}{ }^{-}\right.$, and $\mathrm{SbF}_{6}{ }^{-}$; $\mathrm{H}_{3} \mathrm{~L}^{\mathrm{Me}}=$ Tris[2-((2-methylimidazol-4-yl)methylidene)amino)ethyl]amine). Inorg. Chem. 2003, 42, 8406-8416. [CrossRef] [PubMed]

25. Gómez, V.; Sáenz de Pipaón, C.; Maldonado-Illescas, P.; Waerenborgh, J.C.; Martin, E.; Benet-Buchholz, J.; Galán-Mascarós, J.-R. Easy Excited-State Trapping and Record High T $\mathrm{TIESST}_{\mathrm{T}}$ in a Spin-Crossover Polyanionic Fe(II) Trimer. J. Am. Chem. Soc. 2015, 137, 11924-11927. [CrossRef]

26. Hirosawa, N.; Oso, Y.; Ishida, T. Spin crossover and light-induced excited spin-state trapping observed for an iron (II) complex chelated with tripodal tetrakis (2-pyridyl) methane. Chem. Lett. 2012, 41, 716-718. [CrossRef]

27. Yamasaki, M.; Ishida, T. Spin-crossover thermal hysteresis and light-induced effect on iron (II) complexes with tripodal tris (2-pyridyl) methanol. Polyhedron 2015, 85, 795-799. [CrossRef]

28. Yamasaki, M.; Ishida, T. Heating-rate dependence of spin-crossover hysteresis observed in an iron (II) complex having tris (2-pyridyl) methanol. J. Mater. Chem. C 2015, 3, 7784-7787. [CrossRef]

29. Ishida, T.; Kaneto, T.; Yamasaki, M. An iron(II) complex tripodally chelated with 1,1,1-tris(pyridine-2-yl)ethane showing room-temperature spin-crosssover behaviour. Acta Cryst. 2016, C72, 797-801.

30. Kashiro, A.; Some, K.; Kobayashi, Y.; Ishida, T. Iron(II) and 1,1,1-Tris(2-pyridyl)nonadecane Complex Showing an Order-Disorder-Type Structural Transition and Spin-Crossover Synchronized over Both Conformers. Inorg. Chem. 2019, 58, 7672-7676. [CrossRef]

31. Yamasaki, M.; Ishida, T. First Iron(II) Spin-crossover Complex with an $\mathrm{N}_{5} \mathrm{~S}$ Coordination Sphere. Chem. Lett. 2015, 44, 920-921. [CrossRef]

32. Mekuimemba, C.D.; Conan, F.; Mota, A.J.; Palacios, M.A.; Colacio, E.; Triki, S. On the Magnetic Coupling and Spin Crossover Behavior in Complexes Containing the Head-to-Tail $\left[\mathrm{Fe}_{2}{ }_{2}(\mu-\mathrm{SCN})_{2}\right]$ Bridging Unit: A Magnetostructural Experimental and Theoretical Study. Inorg. Chem. 2018, 57, 2184-2192. [CrossRef] [PubMed]

33. Nebbali, K.; Mekuimemba, C.D.; Charles, C.; Yefsah, S.; Chastanet, G.; Mota, A.J.; Colacio, E.; Triki, S. One-Dimensional Thiocyanato-Bridged Fe(II) Spin Crossover Cooperative Polymer With Unusual FeN $\mathrm{N}_{5}$ Coordination Sphere. Inorg. Chem. 2018, 57, 12338-12346. [CrossRef] [PubMed]

34. White, D.L.; Faller, J.W. Preparation and Reactions of the $C_{3 v}$ Ligand Tris(2-pyridyl)methane and Its Derivatives. Inorg. Chem. 1982, 21, 3119-3122. [CrossRef]

35. Jonas, R.T.; Stack, T.D.P. Synthesis and Characterization of a Family of Systematically Varied Tris(2-pyridyl)methoxymethane Ligands: Copper(I) and Copper(II) Complexes. Inorg. Chem. 1998, 37, 6615-6629. [CrossRef] [PubMed]

36. Guionneau, P.; Marchivie, M.; Bravic, G.; Létard, J.-F.; Chasseau, D. Structural Aspects of Spin Crossover. Example of the $\left[\mathrm{Fe}^{\mathrm{II}} \mathrm{L}_{\mathrm{n}}(\mathrm{NCS})_{2}\right]$ Complexes. Top. Curr. Chem. 2004, 234, 97-128.

37. Sorai, M.; Seki, S. Phonon coupled cooperative low-spin ${ }^{1} \mathrm{~A}^{1} \leftrightarrow$ high-spin ${ }^{5} \mathrm{~T}_{2}$ transition in $\left[\mathrm{Fe}(\mathrm{phen})_{2}(\mathrm{NCS})_{2}\right]$ and $\left[\mathrm{Fe}(\text { phen })_{2}(\mathrm{NCSe})_{2}\right.$ ] crystals. J. Pbys. Chm. Solids 1974, 35, 555-570. [CrossRef]

38. Brehm, G.; Reiher, M.; Le Guennic, B.; Leibold, M.; Schindler, S.; Heinemann, F.W.; Schneider, S. Investigation of the low-spin to high-spin transition in a novel [Fe(pmea)(NCS $\left.)_{2}\right]$ complex by IR and Raman spectroscopy and DFT calculations. J. Raman Spectrosc. 2006, 37, 108-122. [CrossRef]

39. Park, Y.; Jung, Y.M.; Sarker, S.; Lee, J.-J.; Lee, Y.; Lee, K.; Oh, J.J.; Joo, S.-W. Temperature-dependent infrared spectrum of $\left(\mathrm{Bu}_{4} \mathrm{~N}\right)_{2}\left[\mathrm{Ru}(\mathrm{dcbpyH})_{2}(\mathrm{NCS})_{2}\right]$ on nanocrystalline $\mathrm{TiO}_{2}$ surfaces. Sol. Energy Mater. Sol. Cells 2010, 94, 857-864. [CrossRef]

40. Varma, V.V.; Fernandes, J.-R. An Infrared Spectroscopic Study of the Low-Spin-High-spin transition in in $\mathrm{Fe}_{\mathrm{x}} \mathrm{Mn}_{1-\mathrm{x}}(\mathrm{Phen})_{2}(\mathrm{NCS})_{2}$ : A Composition-Induced Change in the Order of the Spin-State Transition. Chem. Phys. Lett. 1990, 167, 367-370. [CrossRef]

41. Sankar, G.; Thomas, J.M.; Varma, V.; Kulkani, G.U.; Rao, C.N.R. An investigation of the first-order spin-state transition in the Fe(Phen) $)_{2}(\mathrm{NCS})_{2}$ EXAFS and infrared spectroscopy. Chem. Phys. Lett. 1996, 251, 79-83. [CrossRef]

42. Smit, E.; de Waal, D.; Heyns, A.M. The spin-transition complexes $\left[\mathrm{Fe}(\mathrm{Htrz})_{3}\right]\left(\mathrm{ClO}_{4}\right)_{2}$ and $\left[\mathrm{Fe}\left(\mathrm{NH}_{2} \operatorname{trz}\right)_{3}\right]\left(\mathrm{ClO}_{4}\right)_{2}$ I. FT-IR spectra of a low pressure and a low temperature phase transition. Mater. Res. Bull. 2000, 35, 1697-1707. [CrossRef] 
43. Durand, P.; Pillet, S.; Bendeif, E.-E.; Carteret, C.; Bouazaoui, M.; El Hamzaoui, H.; Capoen, B.; Salmon, L.; Hébert, S.; Ghanbaja, J.; et al. Room temperature bistability with wide thermal hysteresis in a spin crossover silica nanocomposite. J. Mater. Chem. C 2013, 1, 1933-1942. [CrossRef]

44. Arroyave, A.; Lennartson, A.; Dragulescu-Andrasi, A.; Pedersen, K.S.; Piligkos, S.; Stoian, S.A.; Greer, S.M.; Pak, C.; Hietsoi, O.; Phan, H.; et al. Spin Crossover in Fe(II) Complexes with $\mathrm{N}_{4} \mathrm{~S}_{2}$ Coordination. Inorg. Chem. 2016, 55, 5904-5913. [CrossRef] [PubMed]

45. Bain, G.A.; Berry, J.F. Diamagnetic corrections and Pascal's constants. J. Chem. Educ. 2008, 85, 532-536. [CrossRef]

46. CRYSALIS-CCD 170, CRYSALIS-RED 170; Oxford-Diffraction: Oxfordshire, UK, 2002.

47. Sheldrick, A. SHELX97. Program for Crystal Structure Analysis; University of Gottingen: Gottingen, Germany, 1997.

48. Dolomanov, O.V.; Bourhis, L.J.; Gildea, R.J.; Howard, J.A.K.; Puschmann, H. OLEX2: A complete structure, refinement and analysis program. J. Appl. Crystallogr. 2009, 42, 339-341. [CrossRef]

(C) 2020 by the authors. Licensee MDPI, Basel, Switzerland. This article is an open access article distributed under the terms and conditions of the Creative Commons Attribution (CC BY) license (http://creativecommons.org/licenses/by/4.0/). 